\title{
The shell matrix and microstructure of the Ram's Horn squid: molecular and structural characterization
}

Morgane Oudot $^{1}$, Pascal Neige ${ }^{1}$, Ira Ben Shir ${ }^{2}$, Asher Schmidt ${ }^{2}$, Jan M. Strugnell ${ }^{3,4}$, Laurent Plasseraud $^{5}$, Cédric Broussard ${ }^{6}$, René Hoffmann ${ }^{7}$, Alexander Lukeneder ${ }^{8}$ and Frédéric Marin ${ }^{1 *}$

Authors affiliations:

${ }^{1}$ UMR CNRS 6282 Biogeosciences, University of Burgundy - Franche-Comté, 6 Boulevard Gabriel, 21000 DIJON, France.

${ }^{2}$ Schulich Faculty of Chemistry and Russell Berrie Nanotechnology Institute TechnionIsrael Institute of Technology, Technion City, Haifa 32000, Israel.

${ }^{3}$ Centre for Sustainable Tropical Fisheries and Aquaculture and College of Science and Engineering, James Cook University, Townsville, Qld, 4810, Australia

${ }^{4}$ Department of Ecology, Environment and Evolution, School of Life Sciences, La Trobe University, Kingsbury Drive, Melbourne, Vic. 3086, Australia

${ }^{5}$ Institute of Molecular Chemistry, ICMUB UMR CNRS 6302, University of Burgundy -Franche-Comté, 9 Avenue Alain Savary, Dijon, France.

6 3P5 Proteomic Platform, Cochin Institute, 22 Rue Méchain, Paris, France. 3P5 Proteomic Platform, University of Paris, Cochin Institute, INSERM, U1016, CNRS, UMR8104, F-75014 PARIS, France

${ }^{7}$ Branch Paleontology, Institute of Geology, Mineralogy, and Geophysics, Dpt Earth Sciences, Ruhr-Universität Bochum, Universitätsstrasse 150, 44801 Bochum, Germany.

${ }^{8}$ Natural History Museum Vienna, Burgring 7, 1010 Vienna, Austria.

${ }^{*}$ To whom correspondence should be sent. 
Molluscs are one of the most diversified phyla among metazoans. Most of them produce an external calcified shell, resulting from the secretory activity of a specialized epithelium of the calcifying mantle. This biomineralization process is controlled by a set of extracellular macromolecules, collectively defined as the organic matrix. In spite of several studies, these components are mainly known for bivalve and gastropod classes. In the present study, we investigated the physical and biochemical properties of the internal planispiral shell of the understudied Ram's Horn squid Spirula spirula (Cephalopoda, Decabrachia, Spirulida). Scanning Electron Microscope investigations of the shell reveal a complex microstructural organization, with septa sandwiched into the shell wall, in the form of a bevel. The saccharides constitute a quantitatively important moiety of the matrix, as shown by Fourier-transform infrared spectroscopy. Solid-state nuclear magnetic resonance spectroscopy identified $\beta$-chitin and additional polysaccharides, for a total amount of $80 \%$ of the insoluble fraction. Proteomics was applied to both soluble and insoluble matrices and in silico searches were performed, first on heterologous metazoans models, and secondly, on an unpublished transcriptome of Spirula spirula. In the first case, several peptides were identified, some of them matching with tyrosinase, chitinase 2, protease inhibitor, or immunoglobulin. In the second case, 38 hits were obtained, including transferrin, a serine protease inhibitor, matrilin, different histone-like, a $\alpha$-2-macroglobulin or a putative heme-binding/calcium-binding protein. The very few similarities with known molluscan shell matrix proteins suggest that Spirula spirula uses a unique set of shell matrix proteins for constructing its internal shell. The absence of similarity with closely related cephalopods such as the cuttlefish Sepia demonstrates that there is no obvious phylogenetic signal in the skeletal matrix of cephalopods.

\section{Introduction}

Molluscs, including chitons, oysters, mussels, snails, slugs, octopus and squids, constitute one of the most diversified phyla in the animal kingdom on the basis of shape, anatomy, size, development, habitat or number of living and fossil species (Bouchet et al., 2016; Mora et al., 2011; Ponder et al., 2019; Vinther, 2015). Many molluscs possess an external calcified shell, which protects and anchors the soft tissues of the organisms. This acellular 
epithelium that delineates the mantle, the ciliated organ that coats the inner surface of the shell (Checa, 2018; Simkiss and Wilbur, 1989). The shell fabrication requires specific cellular and molecular machinery: the mineral deposition is indeed controlled by an extracellular organic matrix, which is subsequently occluded. Since its discovery as a key-player in regulating shell biomineralization, the organic matrix has been the subject of a large number of biochemical analyses focused on its protein moieties (Crenshaw, 1972; Hare, 1963; Marin and Luquet, 2004; Rusenko et al., 1991; Sarashina et al., 2006; Weiner, 1983). Most of these studies concentrated their efforts on bivalves and gastropods, the two modern largest mollusc classes. Far less studied are the cephalopods. They represent however an important class, with about 800 living and more than 10000 fossil species (http://cephbase.eol.org/; Nishiguchi and Mapes, 2008). The fossil record indicates that the first indisputable cephalopods appeared in the Middle Cambrian (Kröger et al., 2011) but they may have been present as early as the Lower Cambrian with Tannuella elinorae ( 530 Ma, Brock and Paterson, 2004; Kröger et al., 2011; Vinther, 2015). Since then, cephalopods experienced a complex evolutionary history with important Ordovician, Devono-Carboniferous, Triassic and Cenozoic radiations and major crises, including the end-Permian and end-Cretaceous mass extinctions (Brayard et al., 2009; Murray, 1985; Nishiguchi and Mapes, 2008). From a "biomineralization" viewpoint, cephalopods have a singular evolutionary trajectory (Klug et al., 2019), with a general trend to shell size reduction and internalization (cuttlefish bone), a drastic mineralization decrease (the organic squid pen), leading ultimately to complete loss of skeletal structures, in the most recently appeared cephalopods, i.e., octopuses. Although the clade is commonly recognized as monophyletic, several uncertainties remain regarding the phylogenetic relationships among the major lineages of extant coleoid cephalopods, including that of the internally shelled sepiids (cuttlefishes) and Spirula (Lindgren and Anderson, 2018; Strugnell et al., 2017; Tanner et al., 2017). In addition, the molecular mechanism of shell formation remains poorly known for these taxa.

In this general framework, we focused on the Ram's Horn squid Spirula spirula (Linné, 1758). This species is a small-sized mesopelagic cephalopod (Coleoidea, Decabrachia), rarely observed in its natural environment. It is considered as a monospecific genus (Haring et al., 2012; Neige and Warnke, 2010) and even a monospecific order, whose shell exhibits peculiar characteristics. Some of them are reminiscent of the distantly related Nautilus, such as planispiral coiling and a chambered shell where chambers are separated by concave septa and communicate via a siphuncle, a primordial morphology (plesiomorphic character) within cephalopods. However, the siphuncle of S. spirula is in proximal position, while that of Nautilus 
is more centered in the septa. Furthermore, in contrast to Nautilus sp., the shell of S. spirula is fully internal and its microstructure is not nacreous (as it is in all nautiloids), both characters being considered as derived. These features, among others, are shared with some other coleoids, such as cuttlefishes and relatives (Kröger et al., 2011; Strugnell et al., 2017).

Even though the biology of S. spirula remains largely elusive (Ohkouchi et al., 2013), it is quite common to find shells on beaches of the Atlantic, Indian and West Pacific oceans (Bruun, 1943, Clarke, 1970) and different studies have investigated their microstructure (Cuif et al., 1983, Bandel and Boletzky v., 1979, Dauphin, 1976, 1977). Nevertheless, the shell biochemistry has been explored only very superficially (Dauphin, 1996; Dauphin and Marin, 1995; Degens et al., 1967). The aim of this work is to determine the biochemical characteristics of the shell matrix of S. spirula, with a view to understanding its multiple molecular functions in biomineralization. The second objective of our study is to compare our data with that obtained from better known representatives of the class Cephalopoda and, by extension, of the phylum Mollusca, in order to draw macroevolutionary conclusions.

\section{Material and Methods}

\section{Shell sampling}

All Spirula spirula shell samples used in this study were collected on the beach. They were provided by four of us (R. H., J. M. S., P. N. and A. L.). For subsequent analyses, we used complete shells (Fig. 1) or almost complete, with the exception of the first chamber, frequently

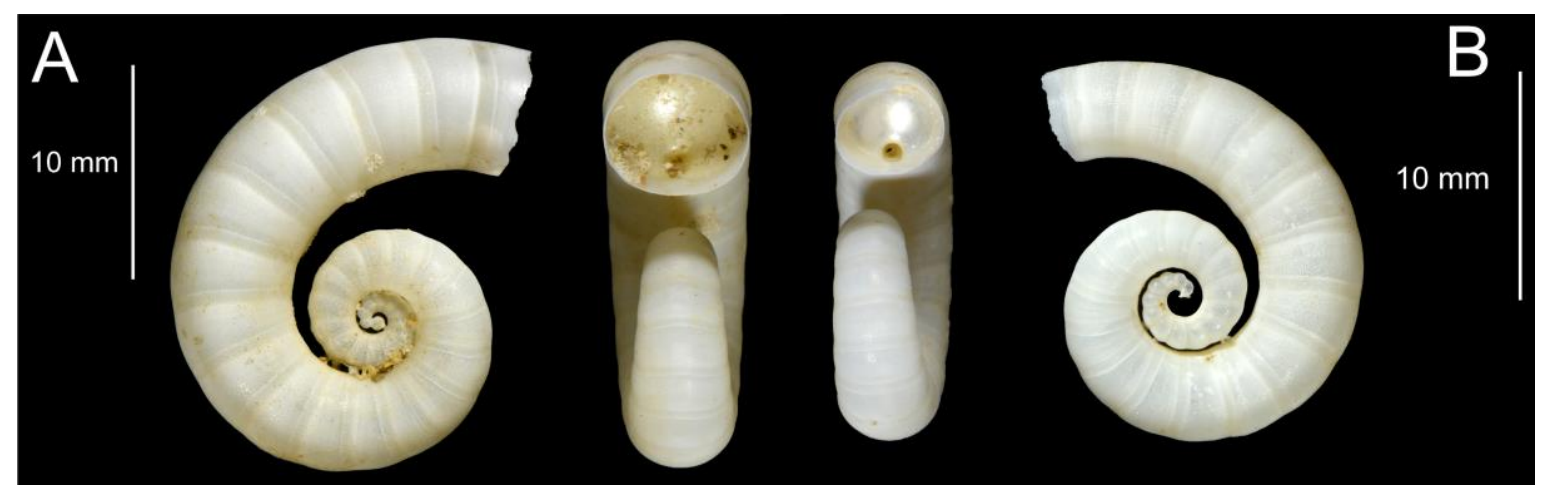

Figure 1: Spirula spirula. A, specimen from East Australian coast (Townsville, Queensland). B, specimen from Thailand. Note that the first specimen still possesses its initial chamber, while it is missing in the second one. 
114 missing. Two batches, consisting of dozens of shells were collected in two locations: the 115 beaches of Lanzarote (Playa de Famara), Canary Islands (R. H., sampling in November 2005), 116 and the beaches of Tamandaré, Pernambuco State, Brazil (sampling in July 2007 and donation 117 to P. N.). Additional material in lesser quantities came from East Australian coast (Townsville, 118 Queensland) (J. M. S.) and from Maldives Islands, Thailand, and Canary Islands (A. L.).

\section{Shell embedding and microstructure analysis}

Shell embedding was performed according to the manufacturer's instructions (Fluka): briefly, benzoyl peroxide (catalyst) was dissolved in the LR White resin monomer solution (9.9 $\mathrm{g}$ per $500 \mathrm{~mL}$ ) for 24 hours, at room temperature, under constant stirring. Complete dried specimens were immersed in sample vials containing the resin solution at room temperature, subsequently placed for a few hours in a desiccator under vacuum. The preparations were incubated at $60{ }^{\circ} \mathrm{C}$ to allow polymerization (three days). The resin blocks were sliced with a saw microtome (Leica SP1600). Shell sections were mirror-polished (0.05 $\mu \mathrm{m}$ aluminium oxide paste) and slightly etched with EDTA solution (1\% wt/vol) for two minutes in an ultrasonic bath, before being rinsed, dried and carbon or gold-coated. The samples were observed with a Hitachi TM-1000 tabletop SEM or with a JEOL JSM-IT 100 InTouchScope ${ }^{\mathrm{TM}}$.

\section{Shell matrix extraction}

The shells were coarsely powdered with a mortar and bleached in a 10-times diluted sodium hypochlorite solution (Merck, 6-14\% active chlorine, ref 105614) for 17 to 20 hours. After several rinsing steps in ultrapure water, the powder was dried at $37{ }^{\circ} \mathrm{C}$ and finely ground manually then divided into two batches. The first one was immediately weighed and decalcified overnight at $4{ }^{\circ} \mathrm{C}$ by adding progressively cold dilute acetic acid $(10 \% \mathrm{vol} / \mathrm{vol})$ at a flow rate of $0.1 \mathrm{~mL}$ every $5 \mathrm{sec}$, under constant stirring (according to the protocol described by Pavat et al., 2012). The second batch was bleached in sodium hypochlorite solution (same concentration) for additional 17-20 hours, rinsed, dried then weighed and decalcified similarly to the first batch.

For each batch, the clear solution was centrifuged (3900 G, 30 min). The supernatant

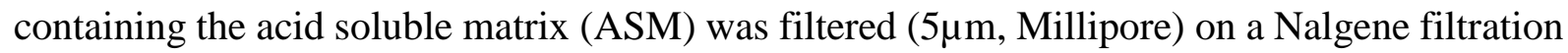

143 device before being ultrafiltered for volume reduction on an Amicon cell (400 mL; cutoff 10 $\mathrm{kDa})$. The solution (10-15 mL) was then extensively dialyzed against Milli-Q water for three 
145 days (6 water changes) and lyophilized. In parallel, the precipitate (i.e. pellet) containing the acid insoluble matrix (AIM) was rinsed via 5 cycles of resuspension in Milli-Q water centrifugation, each supernatant being added to the ASM. Finally, the AIM pellet was

148 lyophilized. All the lyophilisates were weighed on a precision balance (Sartorius Quintix35-

149 1S) three to five times, and the mean value was calculated. In total, three extractions from the 150 Canaries samples were performed, and two from the Brazil ones, leading each time to four 151 batches of extracts, both ASM (ASM1 $1_{b}$ ASM2 ${ }_{b}, A S M 1_{c}$ ASM2 $2_{c}$ ) and AIM (AIM1 $1_{B}$ AIM2 $2_{\text {, }}$ $\left.152 \quad \mathrm{AIM}_{\mathrm{C}} \mathrm{AIM} 2_{\mathrm{C}}\right)$.

FT-IR spectroscopy was performed to identify the shell mineralogy of S. spirula, as well as the overall chemical characteristics of the extracted matrices (ASMs and AIMs). In both cases, minute amounts of samples (shell powder or freeze-dried chips ( $<1 \mathrm{mg}$ ) of ASM and AIM) were analysed with an FT-IR Bruker Alpha spectrometer (Bruker Optics Sarl, Marne-laVallée, France) fitted with an Attenuated Total Reflectance (ATR) ALPHA-P device equipped with a mono-reflection diamond crystal in the $4000-375 \mathrm{~cm}^{-1}$ wavenumber range (24 scans at a spectral resolution of $4 \mathrm{~cm}^{-1}$ ). The qualitative assignment of absorption bands was performed by comparison with previous spectra descriptions, achieved by our group or available in the literature. An additional spectrum was acquired from commercial crab chitin (Sigma, C9752). measurements were carried out on $300 \mathrm{MHz}$ solid state NMR Bruker AVANCE III spectrometer using a $4 \mathrm{~mm}$ triple-resonance MAS NMR probe with zirconia rotors. Samples were spun at $10,000 \pm 2 \mathrm{~Hz}$. Two excitation techniques were employed: DE - direct excitation, and CP Cross Polarization (CP), both using rotor matched chemical shift echo (Stejskal et al., 1977). All experiments employed: $5.0 \mu \mathrm{s} \pi / 2,10.0 \mu \mathrm{s} \pi$ pulse widths, and an echo interval of $100 \mu \mathrm{s}$ identical to the rotor period $T_{\mathrm{R}}$; TPPM ${ }^{1} \mathrm{H}$ decoupling (Bennett et al., 1995) with rf field strength of $100 \mathrm{kHz}$. The Hartmann-Hahn CP employed $50 \mathrm{kHz}$ rf level for the $\mathrm{X}$-channel $\left({ }^{13} \mathrm{C},{ }^{31} \mathrm{P}\right)$ and $50-70 \mathrm{kHz}$ ramped $\mathrm{rf}$ level for the ${ }^{1} \mathrm{H}$ channel with 1 and $2 \mathrm{~ms}$ duration (contact time, ct) for

$173{ }^{13} \mathrm{C}$ and ${ }^{31} \mathrm{P}$ respectively. Experiments were repeated using relaxation delays of $3 \mathrm{sec}\left({ }^{13} \mathrm{C}\right)$ acquiring 8k and 40k transients (Canaries and Brazil samples, respectively) and $3 \mathrm{sec}$ for ${ }^{31} \mathrm{P}$ acquiring $2 \mathrm{k}$ transients. Complementary ${ }^{13} \mathrm{C}$ DE echo MAS NMR measurements were carried 
176

177

178

179

180

181

182

183

184

185

186

187

188

189

190

191

192

193

194

195

196

197

198

199

200

out for the bigger Canaries sample acquiring 64 transients with $200 \mathrm{sec}$ relaxation delay (fully relaxed).

Two Spirula spirula AIM1 extracts - from the Canaries (16.8 mg, AIM1c) and from Brazil (6.0 mg, AIM1B), and a reference chitin standard (Sigma, ref. C9752) were subjected to solid-state MAS NMR measurement. CP MAS is the method of choice to effectively detect organic matter as it takes advantage of the abundant hydrogens as a source of signal, so highlighting all nearby carbons (below $10 \AA$ ) and yielding spectra with high sensitivity (high signal to noise ratio, S/N). Although the quantitative DE MAS spectra are inherently of lower sensitivity, here they were obtained to validate that all peaks (species) are accounted for in the CP spectra.

\section{Mono-dimensional PAGE}

The shell extracts were analyzed by conventional mono-dimensional denaturing SDSPAGE (Bio-Rad, Mini Protean III gels), on precast gradient gels (Mini-PROTEAN TGX Gel 4-15\% acrylamide, $90 \times 70 \mathrm{~mm}$, Bio-Rad) or on homemade gels (12\% polyacrylamide). Prior to migration, the samples were treated as follows: lyophilisates (both ASM and AIM) were dissolved in 2 X Laemmli Sample Buffer (LSB) to a final matrix concentration of $5 \mu \mathrm{g} / \mu \mathrm{L}$. Both preparations were heat-denatured at $100{ }^{\circ} \mathrm{C}: 5 \mathrm{~min}$. for the ASM and $10 \mathrm{~min}$. for the AIM. Note that the AIMs are not fully solubilized by the Laemmli treatment: only the soluble fractions, referred as Laemmli-Soluble AIMs or LS-AIMs, can be visualized on gels. The preparations were cooled down and shortly centrifuged before being applied on the top of the gel. Subsequently, gels were stained by silver nitrate (Morrissey, 1981), carbocyanine, i.e., "Stainsall" (Campbell et al., 1983) and with Bio-Rad blue dye. Other staining methods, such as PAS for glycoproteins and Alcian blue for polyanionic substances, were applied too, but did not produce significant results.

\section{Protein-calcium interaction}

The effect of the Spirula spirula ASM on the growth of calcium carbonate crystals was tested in vitro, as previously described (Albeck et al., 1993) with some modifications (Pavat et al., 2012). In this assay, crystal growth is obtained by slow diffusion of $\mathrm{NH}_{4} \mathrm{HCO}_{3}$ vapor into the $\mathrm{CaCl}_{2}$ solution. To this end, a $10 \mathrm{mM}$ solution of $\mathrm{CaCl}_{2}$ solutions was prepared fresh and filtered ( $5 \mu \mathrm{m}$ pore size) and used for serial dilutions of ASM in the range [0.25-16 $\mu \mathrm{g} / \mathrm{well}$, 
i.e., 1.25 to $80 \mu \mathrm{g} / \mathrm{mL}$ ]. The solutions were incubated in a 16-well culture slide (Lab-Tek, Nunc/Thermo Scientific, Rochester, NY, USA, $200 \mu \mathrm{L}$ per well), which was covered with a plastic cover that had been pierced in the middle of each well to allow vapor diffusion. The whole system was sealed using parafilm "M" laboratory film (Neenah, WI, USA). Finally, the slide was placed in a desiccator containing ammonium bicarbonate crystals that was subsequently closed and placed under vacuum. In parallel, blank controls were performed without ASMs.

After incubation, the slides were carefully dried by gently removing the solution using a blunt-ended syringe needle connected to a vacuum pump. Slides were dis-assembled and the glass plate was observed using a TM1000 tabletop scanning electron microscope (Hitachi) in back-scattered electron mode. To guarantee the reproducibility of the results, the crystallization assay was performed 5 times, each time with a blank control.

\section{Enzyme-Linked Lectin Assay (ELLA)}

Screening of Spirula spirula ASMs by Enzyme-Linked Lectin Assay (ELLA) was performed using a set of 21 biotinylated lectins (Vector Labs, Kits I to III, ref. BK-1000, BK2000, BK-3000 respectively). The binding preferences and specificities of each lectin are indicated in Kanold et al. (2015), which compiles data from different bibliographical sources.

The test was carried out in 96-well microplates (MaxiSorp, NuncTM, Rockslide, Denmark): the Spirula ASM diluted in TBS buffer (200 ng/well) was incubated for $90 \mathrm{~min}$ at $37^{\circ} \mathrm{C}$, immediately followed by three washing steps with TBS/Tween20. Wells were blocked with 1X concentrated Carbo-free blocking solution (Vector Labs, ref. SP-5040) for at least 30 min at $37^{\circ} \mathrm{C}$. The diluted lectins (in TBS/Tween20) were incubated into the microplate for 90 min at $37^{\circ} \mathrm{C}$, at the following dilution factors: 200 times for kits I and II, and 100 times for kit III. After three washes with TBS/Tween20, the microplates were incubated with a diluted solution of Avidin-Alkaline Phosphatase conjugate (1:70000, ref. Sigma A7294, St. Louis, MO, USA) for $90 \mathrm{~min}$ at $37^{\circ} \mathrm{C}$, for the detection of bound biotinylated lectins. They were then washed five times with TBS/Tween20 and revealed with a substrate solution containing aqueous diethanolamine $(9.7 \% \mathrm{vol} / \mathrm{vol}, \mathrm{pH}$ adjusted to 9.8 with $\mathrm{HCl})$ and phosphatase substrate $(0.5 \mathrm{mg} / \mathrm{mL}$, pNPP Tablet, Sigma, St. Louis, MO, USA). The microplates were read at $405 \mathrm{~nm}$ every 15 minutes (BioRad Model 680). A check of the background signal without ASM, lectin or Avidin-AP showed no reaction with the substrate solution. This test was performed with quadruplicates of each lectin and the results were normalized and translated in percentage of 
reactivity by subtracting the background and considering the highest response as $100 \%$. The test was performed three times.

\section{RNA extraction, transcriptome sequencing and assembly}

Tissue samples, collected from a Spirula spirula individual captured from the Coral Sea, Australia, were stored in RNAlater (Qiagen) at $-80^{\circ} \mathrm{C}$. RNA was extracted using an RNeasy Mini Kit (Qiagen) following the manufacturer's protocol. The sample was disrupted using a desktop homogenizer (IKA). RNA quality and quantity were measured using a Bioanalyzer (Agilent). The transcriptome was sequenced on a single lane of an Illumina HiSeq2000 by the Australian Genome Research Facility (AGRF). The transcriptome was assembled from all sequencing data using the assembly program Trinity (Version 2.2, Grabherr et al., 2011). Default parameters were used with data normalization. The Spirula spirula transcriptome assembly included 89,625 contigs and had an average contig length of 625.91 nucleotides. A reference protein database containing 16,405 amino acid sequences was constructed by predicting proteins from the transcriptome using TransDecoder followed by clustering highly similar sequences (95\% identity) with cdhit. Sequencing information is available at NCBI under the BioProject (reference to come).

\section{Proteomic analysis of the shell extracts and subsequent in silico analysis}

MS/MS analyses were conducted on the four unfractionated bulk matrices, ASM and AIM, which were digested in-gel, after a short migration in an $8 \%$ acrylamide gel stained with Coomassie blue. In-gel digestions were carried out with trypsin. Samples were destained twice with a mixture of $100 \mathrm{mM}$ ammonium bicarbonate $(\mathrm{ABC})$ and $50 \%(\mathrm{v} / \mathrm{v})$ acetonitrile (ACN) for $30 \mathrm{~min}$ at $22{ }^{\circ} \mathrm{C}$ and then dehydrated using $100 \% \mathrm{ACN}$ for $15 \mathrm{~min}$, before being reduced with $25 \mathrm{mM} \mathrm{ABC}$ containing $10 \mathrm{mM}$ DTT for $1 \mathrm{~h}$ at $56{ }^{\circ} \mathrm{C}$ and alkylated with $55 \mathrm{mM}$ iodoacetamide in $25 \mathrm{mM} \mathrm{ABC}$ for $30 \mathrm{~min}$ in the dark at $22{ }^{\circ} \mathrm{C}$. Gel pieces were washed twice with $25 \mathrm{mM} \mathrm{ABC}$ and dehydrated (twice, $20 \mathrm{~min}$ ) with $100 \% \mathrm{ACN}$. Gel cubes were incubated with sequencing grade modified trypsin (Promega, USA; $12.5 \mathrm{ng} / \mu \mathrm{l}$ in $40 \mathrm{mM}$ ABC with $10 \%$ ACN, pH 8.0) overnight at $37^{\circ} \mathrm{C}$. After digestion, peptides were extracted twice with a mixture of $50 \% \mathrm{ACN}-5 \%$ formic acid (FA) and then with $100 \%$ ACN. Extracts were dried using a vacuum centrifuge Concentrator plus. 
For MS and MS/MS ORBITRAP, analyses were performed using an Ultimate 3000

271 Rapid Separation Liquid Chromatographic (RSLC) system (Thermo Fisher Scientific) online with a Q-Exactive Plus hybrid quadrupole Orbitrap mass spectrometer (Thermo Fisher Scientific). Briefly, peptides were dissolved in $10 \mu \mathrm{L}$ of $10 \% \mathrm{ACN}-0.1 \%$ trifluoroacetic acid (TFA). Then, peptides were loaded and washed on a $\mathrm{C}_{18}$ reverse phase pre-column $(3 \mu \mathrm{m}$ particle size, $100 \AA$ A pore size, $75 \mu \mathrm{m}$ i.d., 2 cm length). The loading buffer contained $98 \% \mathrm{H}_{2} \mathrm{O}$, $2 \% \mathrm{ACN}$ and $0.1 \%$ TFA. Peptides were then separated on a $\mathrm{C}_{18}$ reverse phase resin $(2 \mu \mathrm{m}$ particle size, $100 \AA$ pore size, $75 \mu$ m i.d., 25 cm length) with a 1 hour gradient from $99 \%$ A ( $0.1 \%$ FA and $\left.100 \% \mathrm{H}_{2} \mathrm{O}\right)$ to $90 \% \mathrm{~B}\left(80 \% \mathrm{ACN}, 0.085 \% \mathrm{FA}\right.$ and $\left.20 \% \mathrm{H}_{2} \mathrm{O}\right)$.

The mass spectrometer acquired data throughout the elution process and operated in a data dependent scheme with full MS scans acquired with the Orbitrap, followed by up to 10 MS/MS HCD spectra. Mass spectrometer settings were full MS (AGC: $3 \times 10 \mathrm{e}^{6}$, resolution: $7 \times 10 \mathrm{e}^{4}, \mathrm{~m} / \mathrm{z}$ range 400-2000, maximum ion injection time: $100 \mathrm{~ms}$ ); MS/MS (AGC: 1x10e , maximum injection time: $100 \mathrm{~ms}$, isolation windows: $4 \mathrm{~m} / \mathrm{z}$ Da, dynamic exclusion time setting: $15 \mathrm{~s})$. The fragmentation was permitted for precursors with a charge state of 2, 3, 4 and up. For the spectral processing, the software used to generate .mgf files is Proteome discoverer 1.4.

Database searches were carried out using Mascot version 2.5 (MatrixScience, London, UK) on 'Other Metazoa' proteins (2,282,777 sequences) from NCBInr databank containing 67,337,701 sequences; 24,122,812,982 residues (April 2018) (http://www.ncbi.nlm.nih.gov/). A second search was performed with the 16405 sequences of the protein-translated transcriptome built from the mantle tissue of Spirula spirula. In each case, the enzyme specificity was trypsin's and up to one missed tryptic cleavage was tolerated. The precursor mass tolerance was set to $4 \mathrm{ppm}$ and the fragment mass tolerance to $20 \mathrm{mmu}$ for Q-Exactive data. Carbamidomethylation of cysteins and oxidation of methionines were set as variable modifications. Hits with human keratines were ignored.

The hits found with the Spirula spirula transcriptome were analysed according to different bioinformatic tools: the identified proteins were blasted against the NCBI dataset "Mollusca", using either BLASTp or Smart BLAST at NCBI; the descriptive protein parameters (molecular weight, isoelectric point, amino acid composition) were assessed with ProtParam and the presence of signal peptide, with SignalP, both tools sheltered by the Expasy Bioinformatics Resources Portal in proteomics (https://www.expasy.org/proteomics). Sequences from the Spirula spirula database that were identified by proteomics were all 


\section{Results}

The different shell microstructures identified in the S. spirula are shown in Figure 2.

307 SEM observations confirmed that the shell wall is constituted of two layers: inner and outer.

308 However, we noticed that the internal one is irregular semi-prismatic (Fig. 2C), while the 309 external one appears as tuberculated and regular semi-prismatic (Fig. 2D), with well-developed 310 spicular crystals. Between these two layers, we can observe a thin blackish layer. Moreover, 311 the septa show a lamello-fibrillar pattern (Fig. 2E), which differs from a nacreous 312 microstructure sensu stricto. We also noticed that the septa progressively insert into the shell 313 wall in the form of a bevel. An observation made at higher magnification revealed that the 314 internal layer progressively changes into the septa (Fig. 2E) with very gradual transition from
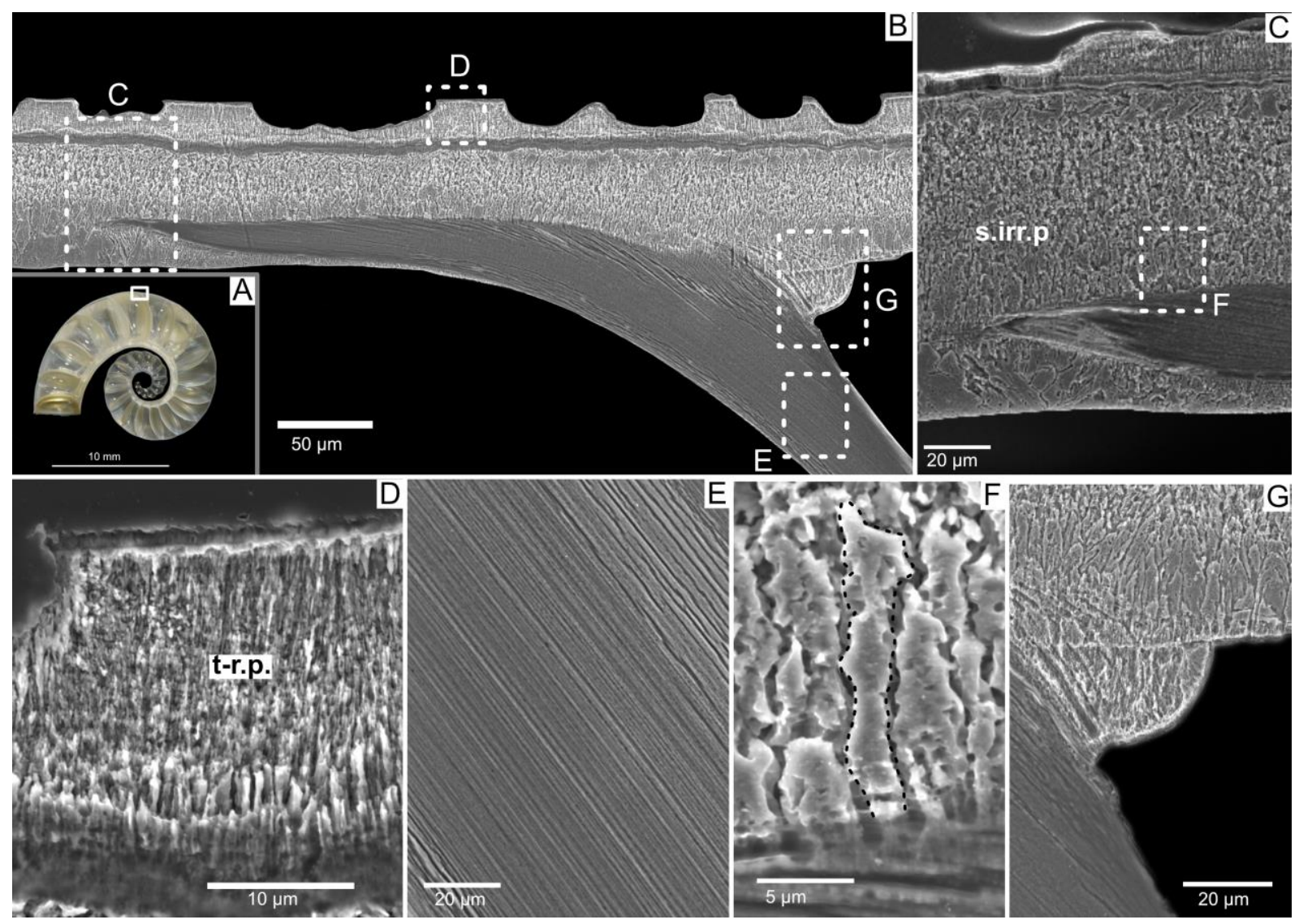

Figure 2: Shell microstructures of Spirula spirula, in the insertion zone of a septum into the shell wall. A) General view, equatorial section. B) General view of the septum insertion in the outer wall. Note the beveled shape of the whole structure. $C$ ) Zoom on the very beginning of the septum into the shell outer wall, showing its organization into an internal unit, with an irregular semi-prismatic layer (s.irr. p). D) Zoom on the external unit of the shell wall, showing its tuberculated and regular semi-prismatic structure (t-r.p). E) Zoom on the lamello-fibrillar structure of the septum. F) Zoom on the contact zone between the septum and the internal shell unit, at the very beginning of the insertion, showing the transformation from the irregular semi-prismatic structure into the lamello-fibrillar one. G) Zoom on the supraseptal annular ridge, observed on the aboral side, dorsal corner, of the septum. In spite of a thin delimitation between the annular ridge and the internal unit, one notices a microstructural continuity. 
315 the prisms to the lamello-fibrillar aspect of the septa. Finally, we noticed a little bulge in the

316 aboral side of the septa, in the top corner between them and the shell wall (Fig. 2F).

Matrix quantification of the last extraction is shown in Table 1. However, we did not detect any significant variations between the different extractions, in term of absolute quantities 321 of matrices, both ASM and AIM. Thus, we can consider that this quantification reflects 322 accurately the amount of organics in the shell of $S$. spirula. After a single bleaching step, the 323 composition of the matrix is dominated by acetic acid-insoluble components (AIM) that 324 represent between two-third and four-fifth of the total matrix (around 70\%). The latter accounts 325 for about $1 \%$ of the shell powder weight ( 0.7 and $1.09 \%$, respectively). The second bleaching has a drastic effect on the AIM, since the weight values of this matrix collapse to unquantifiable amounts for the Brazil samples. The effect is less pronounced for the ASM, the absolute quantity of which is divided by a factor 2 to 2.5 .

FT-IR (ATR) spectra acquired from eight extracts of AIM and ASM fractions are shown

\begin{tabular}{|c|c|c|c|c|c|c|}
\hline & & Initial weight (g) & ASM extract (mg) & \%ASM & AlM extract (mg) & $\%$ AIM \\
\hline \multirow{2}{*}{ Canary Islands } & Batch 1 & 2.0832 & 5.36 & $0.25 \%$ & 22.6 & $1.09 \%$ \\
\cline { 2 - 7 } & Batch 2 & 2.0315 & 2.00 & $0.1 \%$ & 0.35 & $0.01 \%$ \\
\hline \multirow{2}{*}{ Brazil } & Batch 1 & 1.6093 & 6.24 & $0.39 \%$ & 11.2 & $0.7 \%$ \\
\cline { 2 - 7 } & Batch 2 & 1.6103 & 3.98 & $0.24 \%$ & N/A & N/A \\
\hline
\end{tabular}

Table 1: Summary of the quantity and proportion of each organic shell matrix fraction (ASM, AIM) after on (batch 1) or two (batch 2) bleaching treatments. Separate data were obtained for samples of two different geographical sources, Canary Islands and Brazil.

332 in Figure 3. Two additional spectra, corresponding to shell powder and commercial chitin $(\alpha-$ 333 type), respectively, are also depicted at the top of the figure. For more details and to facilitate 
334 the comparison, the spectra exclusively

335 focus on the range of $2000-400 \mathrm{~cm}^{-1}$ (full

336 FT-IR data are depicted in the

337 supplementary Figure 1). Firstly, we

338 verified that the mineralogy of the samples

339 was fully aragonitic - characterized in

340 particular by the $700-713 \mathrm{~cm}^{-1}$ double peak

341 ( $v_{4}$ internal vibration modes of $\mathrm{CO}_{3}{ }^{2-}$ )

342 (Balmain et al., 1999) - by checking

343 different zones of the shell (initial

344 chamber, one random intermediate

345 chamber, last preserved chamber). For

346 clarity, only the spectrum acquired from

347 the powder of the last chamber is shown in

348 Fig. 3 (top spectrum-shell powder). In the

$3492500-4000 \mathrm{~cm}^{-1}$ range (not shown in Fig.

350 3), the shell matrix samples exhibit one

351 broad band located at $3271 \mathrm{~cm}^{-1}$, which is

352 usually attributed to the amide A group

$353[v(\mathrm{~N}-\mathrm{H})]$ (Kong and $\mathrm{Yu}, 2007)$. In

354 addition, one low amplitude enlarged band

355 centered at $2932 \mathrm{~cm}^{-1}$ can be observed, and

356 usually assigned to the $v(\mathrm{C}-\mathrm{H})$ stretching

357 vibrations.

$358 \quad$ All extracts (8) show comparable

359 fingerprints and a strong similarity in the

360 distribution of their absorption bands. To

361 facilitate comparisons, we have compiled

362 the FT-IR profiles in pairs of samples from

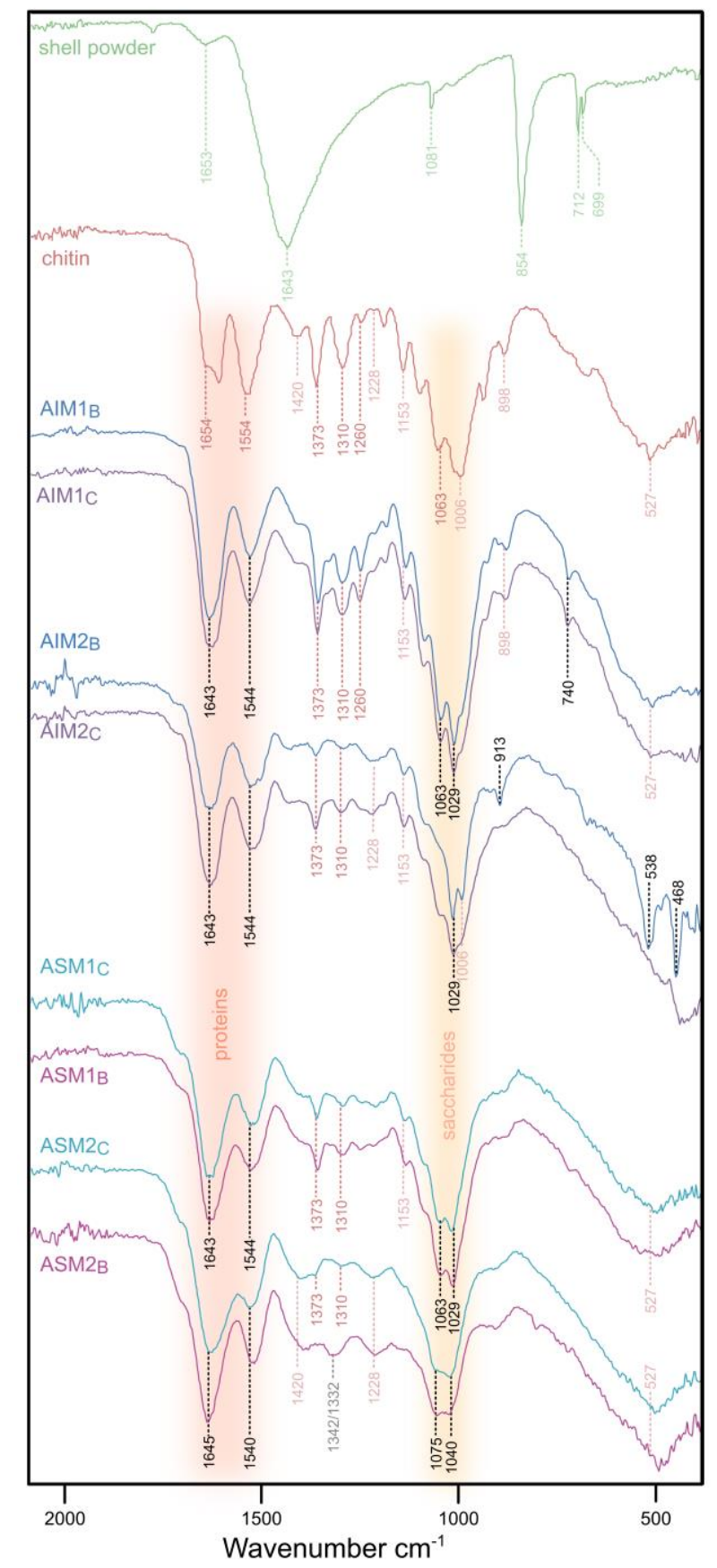

Figure 3: FT-IR spectra of the shell powder of Spirula spirula, of commercial $\alpha$-chitin and of the different organic fraction of the shell matrix (AIM1, AIM2, ASM1, ASM2) from both localities (i.e. Canaries and Brazil). The "domains" of the characteristic absorption bands of protein and saccharidic moieties are highlighted, respectively, in pink and yellow. The values of the main absorption peaks are indicated under each of them, and colored in pink when identical to those of the commercial chitin.

363 Brazil (B) and Canary Islands (C): AIM1 $1_{\mathrm{B}} / \mathrm{AIM} 1_{\mathrm{C}}, \mathrm{AIM} 2_{\mathrm{B}} / \mathrm{AIM} 2_{\mathrm{C}}, \mathrm{ASM} 1_{\mathrm{C}} / \mathrm{ASM} 1_{\mathrm{B}}$ and

364 ASM2C/ASM2 $2_{B}$. Unambiguously, all spectra exhibit, in particular, the presence of amide 365 absorption bands at $1638 / 43$ and $1535 / 43 \mathrm{~cm}^{-1}$, ascribed to the Amide I $[v(\mathrm{C}=\mathrm{O})]$ and II $366[v(\mathrm{C}-\mathrm{N})]$ bands, respectively, that characterize protein moieties. In addition, AIM and ASM 
fractions are also characterized by a high density of absorption bands between 1500 and 1000 $\mathrm{cm}^{-1}$, very similar to those observed for commercial $\alpha$-chitin. The most significant are located at $1420,1373,1310$ and $1260 \mathrm{~cm}^{-1}$, and can be attributed to $\delta\left(\mathrm{CH}_{2}\right), \delta_{s}\left(\mathrm{CH}_{3}\right), \delta(\mathrm{C}-\mathrm{H})$ and amide I bands, respectively. Moreover, absorptions of stretching vibrations of saccharidic moieties are clearly revealed by the presence of intense absorptions at 1153,1063 and $1006 \mathrm{~cm}^{-1}$ corresponding to $v_{\mathrm{s}}(\mathrm{C}-\mathrm{O}-\mathrm{C}), v_{a s}(\mathrm{C}-\mathrm{O}-\mathrm{C})$, and $v(\mathrm{C}-\mathrm{O})$, respectively (Kaya et al., 2014) . The spectra from both origins - Canary Islands and Brazil - are very similar. It is interesting to note that the AIM2 $2_{\mathrm{B}}$ spectrum exhibits additional bands, sharp and of medium intensities, between 1000 and $400 \mathrm{~cm}^{-1}$ (located at 913, 538, $468 \mathrm{~cm}^{-1}$ ). To the best of our knowledge, and based on the existing bibliography, these bands suggest the presence of phosphate groups $\left(\mathrm{PO}_{4}{ }^{3-}\right)(\mathrm{Radev}$ et al., 2012). Thus, the band at $913 \mathrm{~cm}^{-1}$ can be assigned to the stretching $\mathrm{P}-\mathrm{O}$ vibrations and those at 538 and $468 \mathrm{~cm}^{-1}$ can be related to the bending $\mathrm{O}-\mathrm{P}-\mathrm{O}$ vibrations of phosphate groups (Jastrzbski et al., 2011). At this stage of investigations, the reason of this variance from other samples remains still undetermined. However, in recent studies on other shells of marine animals, such as Pinctada margaritifera (Schmitt et al., 2018) and Porites australiensis (Takeuchi et al., 2018), we already made the same spectroscopic observations on AIM fractions leading to comparable suppositions about the presence of $\mathrm{PO}_{4}{ }^{3-}$ groups.

When compared to AIMs, ASMs show a decrease in intensity of the amplitude of their absorption bands in the $1200-1420 \mathrm{~cm}^{-1}$ range. It is the same for the saccharidic bands of ASMs also showing a relative intensity decrease in comparison to that of amide absorptions. Finally, we observe that the second bleaching treatment alters the amplitude of the absorption bands in the $1200-1420 \mathrm{~cm}^{-1}$ range, without modifying the overall appearance of spectra.

\section{Solid State Nuclear Magnetic Resonance}

The ${ }^{13} \mathrm{C}$ CP MAS NMR spectra of the two Spirula spirula extracts (AIM1) and of $\alpha-$ chitin standard are shown in Figure 4. The spectra from both origins - Canary Islands and Brazil - are closely identical, and are dominated by the characteristic chitin peaks. The latter are superimposed on a much weaker set of partially resolved peaks between 20 and 55 ppm, which are consistent with small residual proteinaceous content. The merged $C_{3}$ and $C_{5}$ peaks, the broadened methyl peak, and the chemical shifts of $C_{1}$ and $C_{4}$ peaks (103.9 and $\left.83.9 \mathrm{ppm}\right)$ in the ${ }^{13} \mathrm{C}$ CP MAS spectra of the $S$. spirula samples are consistent with $\beta$-chitin (Jang et al., 2004; Kaya et al., 2017). 
The chitin peaks exhibited by both $S$.

400 spirula extracts deviate from those of the neat

401 chitin peaks, showing broadening and reversed

402 relative $C_{6}$ and $C_{2}$ peak intensities (increased

403 and decreased, respectively); these deviations

404 represent increased structural heterogeneity due

405 to modification and/or disruption of local

406 environments possibly as a result of the

407 extraction procedure. Closer inspection of the

408 spectra reveals additional partially resolved

409 peaks (102.6, 86.3, and 71.5 ppm respectively;

410 supplementary Fig. 2) that appear as shoulders

411 of the $C_{1}, C_{4}$ and $C_{5}$ peaks; these suggest

412 contributions from other polysaccharides. Given

413 the increased linewidths, the co-occurrence of

414 the other chitin polymorphs cannot be ruled out.

415 In conclusion, the spectra imply that over $80 \%$

\section{S.spirula (Canaries)}

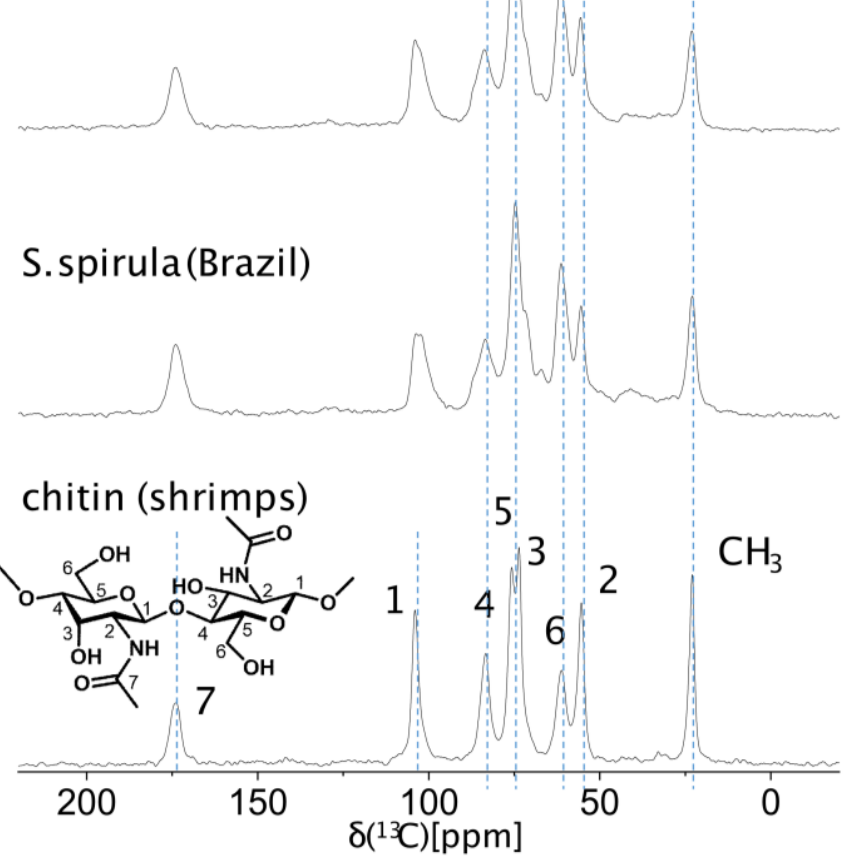

Figure 4: $75.4 \mathrm{MHz}$ 13C CPMAS spectra of acid insoluble extracts (AIM1) of Spirula spirula shells from the Canaries and Brazil, and of $\alpha$-chitin standard (shrimp) showing that the organic content of AIMI consists primarily of chitin (the dashed lines denote the characteristic peaks of chitin).

416 of the insoluble organic extract content (AIM1)

417 is chitinous/saccharidic. This determination is further substantiated by the lower S/N DE MAS

418 spectrum shown in Figure 4.

$419 \quad$ Both S. spirula AIM1 extracts show a

420 broad -0.2 ppm phosphate peak in their ${ }^{31} \mathrm{P} \mathrm{CP}$

421 MAS spectra (Figure 5), validating the above IR

422 findings for the $\mathrm{AIM} 2$ samples. ${ }^{13} \mathrm{C}\left\{{ }^{31} \mathrm{P}\right\} \mathrm{CP}$

423 MAS REDOR measurements applied to AIM1C

424 showed no REDOR effect (not shown) therefore

425 ruling out phosphorylation of any of the chitin

426 carbons. In the absence of such measurable

427 proximity and in view of the resilience of these $\mathrm{P}$ -

428 species under the extraction procedures (AIM1

429 and the more aggressive of AIM2), we conclude

S. spirula (Brazil)

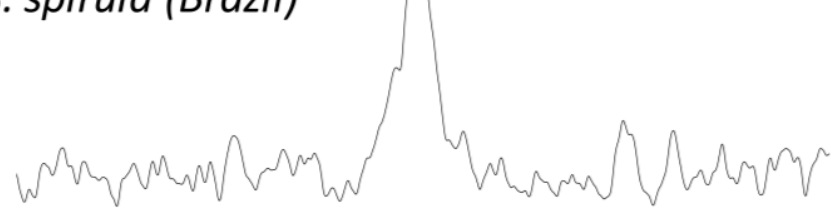

\section{S. spirula (Canaries)}

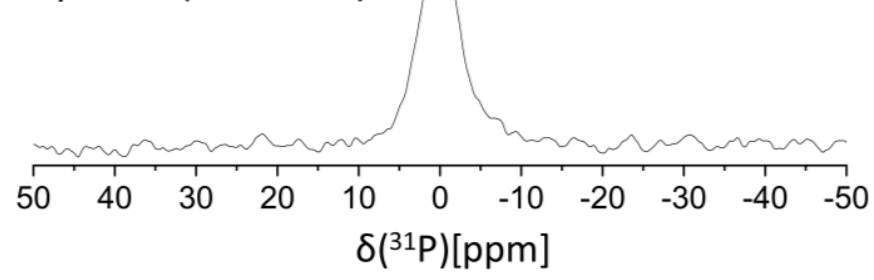

Figure 5: 121.85 MHz 31P CP MAS NMR spectra of the acid insoluble extract (AIM1) of Spirula spirula shells from the Canaries and Brazil. The peaks are centered at -0.2 ppm and are of similar normalized intensities (accounting for sample weights of 16.8 and $6.0 \mathrm{mg}$, respectively). Each spectrum was obtained acquiring $2 k$ transients.

430 that the observed P-species are inseparable from

431 the proteinaceous content. We have previously reported similar ${ }^{31} \mathrm{P}$ peak for decalcified 
432 molluscs shells (Agbaje et al., 2018), and also here we ascribe this peak to represent 433 phosphorylation, most likely of tyrosine and/or serine side chains.

The results obtained after migrating the eight matrices in denaturing conditions are 436 illustrated in Figure 6. In the silver stained gel (Fig. 6A), all of them are characterized by the 437 abundance of smearing macromolecules along the whole lane, in particular in the LS-AIMs 438 extracts. In addition, discrete bands, either blurred like the ones of low molecular weights $(<17$ $439 \mathrm{kDa}$ ) in lanes $1,3,5$ and 7, or thin and tenuous such as in the middle of the lanes 3 and 7, can 440 be observed. We notice that the electrophoretic profiles produce superimposable patterns 441 between similar extracts but from the two locations (such as those of lanes 1 and 5, 3 and 7). 442 The effect of the second bleaching treatment is mainly visible on the ASMs extracts: 443 disappearance of the high molecular diffused black band (above $170 \mathrm{kDa}$, lanes 1 and 5 versus 444 lanes 3 and 7, respectively), and appearance of a set of four bands between 30 and $43 \mathrm{kDa}$ 445 (respectively 32.4, 35.88, 38.69 and $42.05 \mathrm{kDa}$ ). The Bio-Rad blue dye (Fig. 6B) stains mainly
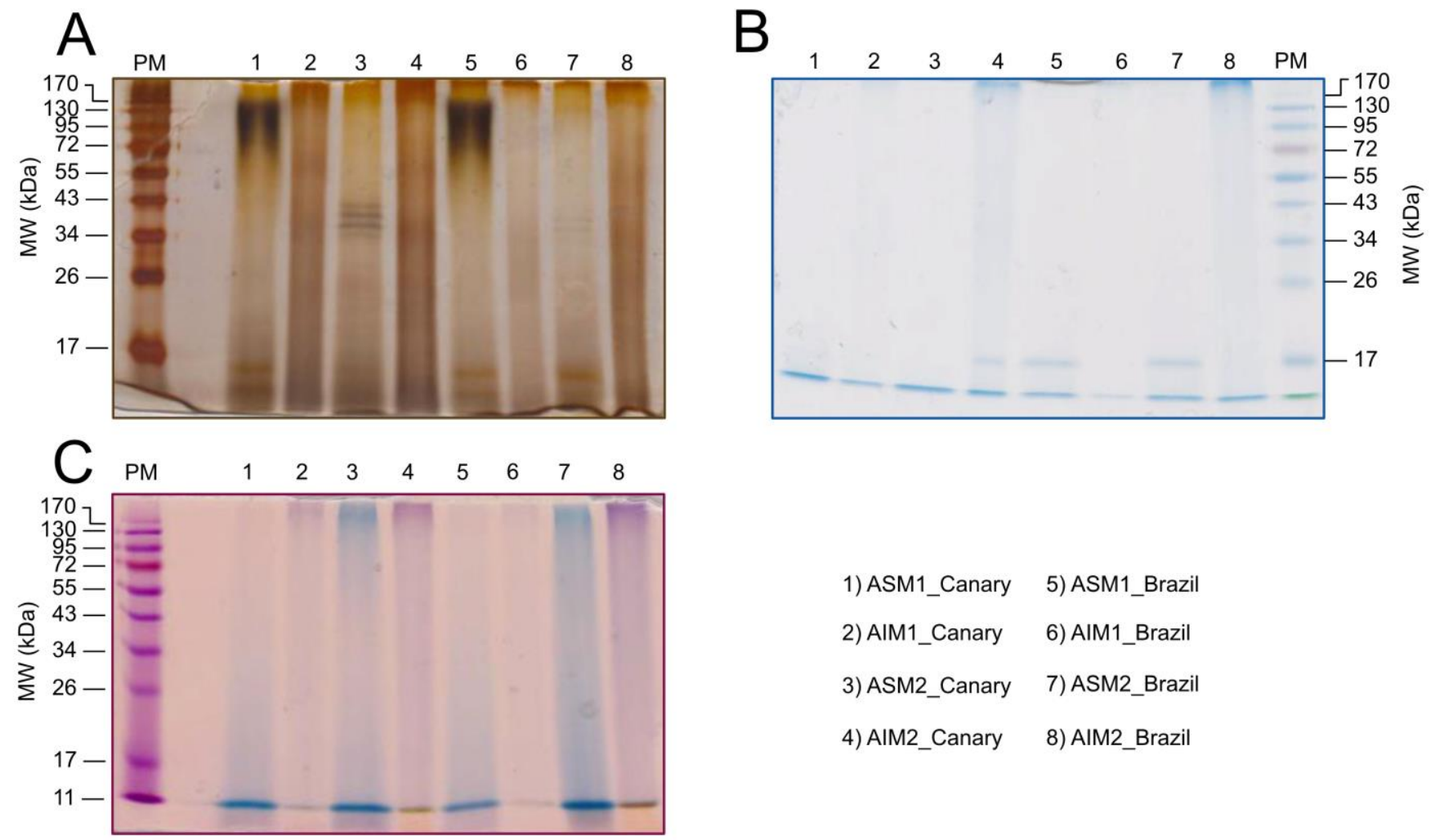
1) ASM1_Canary
5) ASM1_Brazil
2) AIM1_Canary
6) AIM1_Brazil
3) ASM2_Canary
7) ASM2_Brazil
4) AIM2_Canary
8) AIM2_Brazil 
446 low molecular weight macromolecules, in particular the $17 \mathrm{kDa}$ band, observed in lanes $4,5,7$

447 and 8. Note that lanes 4 and 8 (LS-AIMs) are equally stained along their length, except a very

448 high molecular weight fraction, which is intensely marked. The carbocyanine dye, which is 449 supposed to stain calcium-binding macromolecules (Fig. 6C), discriminates the ASMs from the 450 LS-AIMs: the first ones are stained blue, and the second, purple. None of the discrete bands 451 observed in silver stained gels are visible with carbocyanine, except the migration front, which 452 is intensely dyed in all cases. For all LS-AIMs, one notices in the migration front the 453 superimposition of an additional greenish color (lanes 2, 4, 6, 8) that may suggests the presence 454 of low molecular weight colored components, such as pigments. In some of our other attempts, 455 we could lightly stain in the ASMs two discrete bands, one at $17 \mathrm{kDa}$ and another one at very 456 high molecular weight (supplementary Fig. 3).

The effect of the addition of the two soluble extracts, ASM1 and ASM2, when tested in 459 the range [0 - $16 \mu \mathrm{g} / \mathrm{well}]$, is shown in Figure 7, which only presents few of the tested 460 concentrations $(0,1,4$ and $16 \mu \mathrm{g} / \mathrm{well})$. We notice that the effect of the first one (upper panel) 461 is limited at all tested concentrations: we do not observe any significant differences with the 462 blank, up to $4 \mu \mathrm{g} / \mathrm{well}$. Starting from $8 \mu \mathrm{g} /$ well (not shown here), the effect becomes

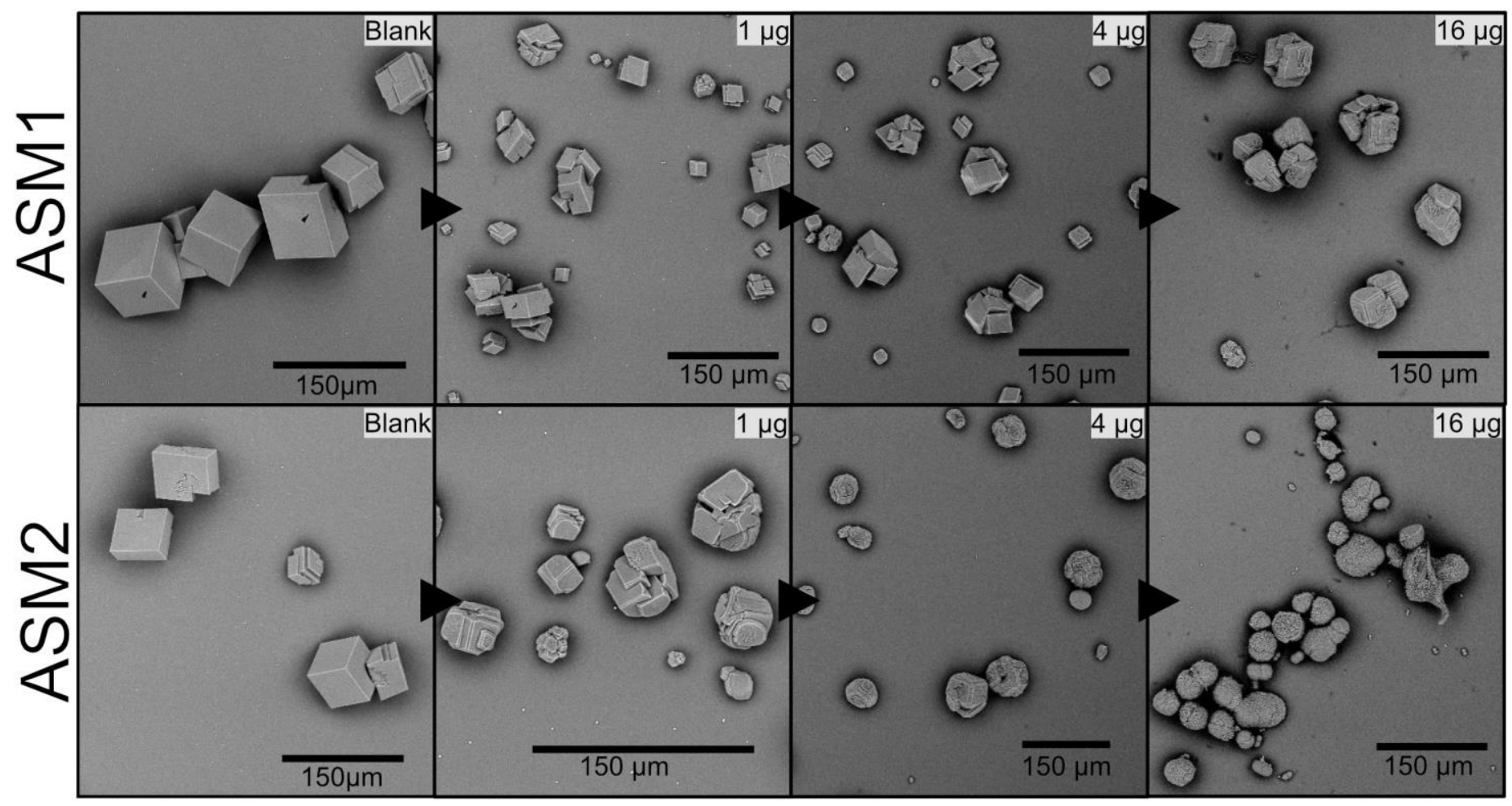

Figure 7: In-vitro crystallization assay performed on both soluble matrix extracts of Spirula spirula, ASM1 (top) and ASM2 (bottom). The black arrows indicate the increasing matrix concentration within each well, from 0 (blank) to $16 \mu \mathrm{g} /$ well ( $200 \mu \mathrm{L}$ per well). 
progressively visible, with the formation of grooves on the polycrystalline aggregates edges. At

$46416 \mu \mathrm{g} / \mathrm{well}$, the effect is more pronounced with the formation of rounded angles. No signs of crystallization inhibition - characterized by a drastic decrease of the size of polycrystalline aggregates - are recorded with ASM1.

The effect of ASM2 (lower panel) appears much more drastic. At $1 \mu \mathrm{g} / \mathrm{well}$, grooves are already visible on the crystal faces edges, while the $4 \mu \mathrm{g}$ condition resembles the $16 \mu \mathrm{g}$ one of ASM1. At $16 \mu \mathrm{g}$, polycrystalline aggregates evolve into complex spherulite, without any significant size changes.

All screening

experiments

474 performed with a large set of commercial

475 lectins are summarized in Table 2. We

476 analyzed only ASMs: the insolubility of

477 AIMs in standard buffers precluded the

478 use of ELLA. Firstly, we do not detect

479 significant variations of lectin reactivity

480 between Canaries Island extracts and that

481 of Brazil: the few low amplitude

482 variations concern a couple of lectins that

483 either do not react or react very weakly

$484(10-20 \%)$, such as LCA or GSL-1. To

485 summarize, we obtain three classes of

486 reactivity: high, intermediate and low. In

487 the first class, one finds LEL, WGA, STL

488 (only for ASMs1) and Jacalin. The three

489 first lectins bind oligomers (dimers and

490 trimers in the case of WGA) of $\mathrm{N}$ -

\begin{tabular}{|c|c|c|c|c|}
\hline & \multicolumn{2}{|c|}{ Canary Islands } & \multicolumn{2}{c|}{ Brazil } \\
\hline & ASM1 & ASM2 & ASM1 & ASM2 \\
\hline ConA & $X X$ & $X X X$ & $X X$ & $X X X$ \\
\hline SBA & - & - & - & - \\
\hline WGA & $\mathrm{XXXX}$ & $\mathrm{XXXX}$ & $\mathrm{XXXX}$ & $\mathrm{XXXX}$ \\
\hline DBA & - & - & - & - \\
\hline UEA 1 & - & - & - & - \\
\hline RCA & - & - & - & - \\
\hline PNA & - & - & - & - \\
\hline GSL 1 & - & $\mathrm{X}$ & - & - \\
\hline PSA & - & - & - & - \\
\hline LCA & - & - & $\mathrm{X}$ & $\mathrm{X}$ \\
\hline PHA-E & - & - & - & - \\
\hline PHA-L & - & - & - & - \\
\hline SJA & - & - & - & - \\
\hline succ-WGA & $\mathrm{XX}$ & $\mathrm{X}$ & $\mathrm{XXX}$ & $\mathrm{X}$ \\
\hline GSL 2 & $\mathrm{X}$ & $\mathrm{X}$ & $\mathrm{X}$ & $\mathrm{XX}$ \\
\hline DSL & $\mathrm{X}$ & - & $\mathrm{XX}$ & - \\
\hline ECL & - & - & - & - \\
\hline Jacalin & $\mathrm{XX}$ & $\mathrm{XXXX}$ & $\mathrm{XXX}$ & $\mathrm{XXXX}$ \\
\hline LEL & $\mathrm{XXXX}$ & $\mathrm{XXXX}$ & $\mathrm{XXXX}$ & $\mathrm{XX}$ \\
\hline STL & $\mathrm{XXXX}$ & $\mathrm{X}$ & $\mathrm{XXXX}$ & $\mathrm{X}$ \\
\hline VVA & - & - & - & - \\
\hline
\end{tabular}

Table 2: Summary of the reactivity pattern of lectins on both soluble fractions (ASM1 and ASM2) for both localities. 'XXXX' indicates a reactivity that exceeds $60 \%$, ' $X X X$ ', a reactivity comprised between 40 and $60 \%$, ' $X X$ ' between $20-40 \%$, 'X', between $10-20 \%$ and '-' for a reactivity below $10 \%$.

491 acetylglucosamine and are usually considered as chitin-binding lectins. Jacalin binds 492 preferentially D-galactose or oligomers that terminate with galactose residues, as well as N493 acetylgalactosamine-D-galactose dimers that very often correspond to the first glycosylation 494 steps of Ser/Thr residues in O-glycosylated proteins. The second category of reactivity comprises ConA, succinylated-WGA and, in a lesser extent, GSL-II, and DSL. ConA binds 
specifically to mannose- $\mathrm{N}$-acetylglucosamine dimers and is also considered as a mannose-

497 binding lectin when this residue is part of N-linked oligosaccharides. Succinylated-WGA has similar binding properties as native WGA, but its binding capacity is inhibited by sialic acid. Thus, linking the reactivities of native and succinylated WGAs informs on the degree of sialylation of the tested extract. GSL-II and DSL bind either oligomers (DSL) or monomers (GSL-II) of $\mathrm{N}$-acetylglucosamine, the latter one binding specifically the terminal residues. The third category groups all the other lectins that give weak or no signal with the tested extracts, and will not be discussed further.

Although the reactivity patterns are very similar between ASM1 and ASM2, it is interesting to notice that the second bleaching step modifies the signal given by few lectins, suggesting that the saccharidic groups targeted by the diverse lectins are differentially exposed to sodium hypochlorite: in particular, STL collapses drastically, while, inversely, Jacalin increases significantly. Other minor variations are recorded: Succ-WGA and DSL tend to decrease whereas ConA rises substantially.

Proteomic analysis

\begin{tabular}{|c|c|c|c|c|c|c|}
\hline & & AIM1 & ASM1 & AIM2 & ASM2 & TOTAL \\
\hline \multirow{3}{*}{ A } & Total number of hits & 47 & 17 & 44 & 33 & 141 \\
\hline & Number of unique hits & 22 & 5 & 19 & 15 & 61 \\
\hline & $\begin{array}{l}\text { Number of shared hits between } 2 \text { or more } \\
\text { extracts }\end{array}$ & 25 & 12 & 25 & 18 & 30 \\
\hline & & & & & & \\
\hline \multirow{4}{*}{ B } & AIM1 & & 8 & 21 & 14 & \\
\hline & ASM1 & & & 8 & 8 & \\
\hline & AIM2 & & & & 15 & \\
\hline & ASM2 & & & & & \\
\hline
\end{tabular}

\begin{tabular}{|c|c|c|c|c|c|c|}
\hline \multirow{13}{*}{$\mathrm{C}$} & Number of identified peptides & 82 & 20 & 55 & 42 & 199 \\
\hline & Number of hits identified by 2 or more peptides & 4 & 2 & 5 & 6 & 17 \\
\hline & Number of hits identified by 1 peptide & 43 & 15 & 39 & 27 & 124 \\
\hline & \multirow{10}{*}{ Dominant AA residues in the identified peptides } & Leu: 13.7 & Leu: 13.6 & Leu: 10.5 & Leu: 10.8 & \\
\hline & & Ile: 8.7 & Val: 8.9 & Ile: 9.6 & Ile, Val: 8.4 & \\
\hline & & Asp: 8.3 & Ala, Arg, Glu: 8.4 & Val: 8.8 & Thr: 8.1 & \\
\hline & & Arg: 7.5 & Pro, Ser: 6.3 & Asp, Gly: 8.0 & Glu: 7.9 & \\
\hline & & Ala: 7.2 & Asp, Thr: 5.8 & Arg: 7.8 & Arg: 7.4 & \\
\hline & & Glu: 7.0 & Ile: 5.2 & Ala: 7.1 & Ala: 6.9 & \\
\hline & & \multicolumn{2}{|c|}{ Gly, Val, Ser: 6.4} & Ser: 6.8 & Asp: 6.7 & \\
\hline & & Thr: 6.0 & & Pro: 6.4 & Ser: 6.2 & \\
\hline & & Pro: 5.5 & & Thr: 6.3 & Pro: 5.5 & \\
\hline & & & & Glu: 5.8 & & \\
\hline
\end{tabular}

Table 3: Overview of the main proteomic results by MASCOT. A) Summary of the identified hits per extract. B) Crosscomparison of shared hits in the 4 extracts. C) Summary of the identified peptides per extract and occurrence of the most represented AA residues (sorted by decreasing order and colored according to their chemical properties: Blue: basic; red: acidic; orange; hydroxylated; green: hydrophobic) 

was performed on two databases: in the first case, we searched against "Other metazoans" NCBI dataset, and, in the second case, against the Spirula spirula transcriptome. The results of the

514 first approach are summarized in Table 3. In addition, Table 4 represents the list of peptides identified for each extract and Table 5,the hits shared by the different extracts. The overall proteomic results are available in the Supplementary Table 1. In total, 141 hits are obtained, and after suppressing duplicates, 91 (Table 3A). This score is particularly low. We notice that the two ASMs extracts yielded less hits than their insoluble counterparts. Unique hits represent about $40-45 \%$ of the total number of identified hits, except for ASM1, where it only accounts for $29 \%$. In short, 22 hits are unique to AIM1, 19 to AIM2, 5 to ASM1 and 15 to ASM2. By focusing on shared hits (Table 3B), we notice that AIM1 and AIM2 are the most similar (21 hits), followed by ASM2, which exhibits some similarities with insoluble extract (14 shared hits with AIM1, and 15 with AIM2). ASM1 appears to be the most different extract from the four ones. Table 3C shows the number of identified peptides, combined to the occurrence of the main amino acid residues in each shell extract. It shows that very few hits (less than $20 \%$ of the total matches per extract) are identified by two or more peptides, the remaining hits being recognized by only one peptide. A brief survey of the number of identified peptides per extract confirms our previous finding, namely that both AIMs exhibit higher number of peptides than

\begin{tabular}{|c|c|}
\hline $\begin{array}{l}\text { AIM1 } \\
(13959)\end{array}$ & $\begin{array}{l}\text { AGGFAGDDAPR ; GYSFTTTAER ; EISALAPATMK ; QEYDESGPSIVHR ; SYELPDGQVITIGNER ; VAPEEHPVLLTEAPLNPK ; } \\
\text { DLYANTVLSGGSTMFPGIADR ; TTGIVMDSGDGVTHTVPIYEGYALPHAILR ; EITALAPSTMK ; VAIVITDGR ; DYAIVDER ; STELLIR ; ISGLIYEETR ; } \\
\text { TITLEVEPSDTIENVK ; DEVLGGILR ; LILPGELAK ; GDGTGGLSIYGDR ; IDVADLLR ; SPNQNVQQAAAGALR ; VAVDTSYR ; SPIDLVR ; IDLLIPR ; } \\
\text { ITIDLFEK ; IVMSQGTHLYFDHPYEPDPEER ; VSIVITDGR ; LDSDIKPQMKR ; TPTDVPVNLSCGR ; QLVQDSLDSLR ; ANILSILEK ; KLVLLNYER ; } \\
\text { YSPVDPIR ; QSIESVSPR ; LGIYEDFGTK ; IVIGLFGK ; IAFLVLK ; DSTLIMQLLR ; ELQDLNER ; LFDQAFGLPR ; DALEELDADR ; KILSIVER ; EGIEAIEDDR ; } \\
\text { LDILPLK ; DLVGELADAIR ; QLSGQQYR ; LDTELNTYR ; VLSIILEK ; QLLEEIANLQK ; NIIDLNTEMK ; LMASFER ; LLLTAAISADK ; KINPPYYR ; } \\
\text { ATSQTLLDENDITFR ; ATLGLPQPK ; VATVPLSR ; TGVSSEGDTDKR ; TTGIVMDSGDGVTHTVPIYEGYALPHAIIR ; SPLDLVR ; } \\
\text { VVMTQASHLYFDHPYEPDPEER ; ASLVLDTGR ; LDLLPLR ; IGGIGTVPVGR ; IADADFR ; IASYLEK ; LGTALPFVR ; DYLQIVDAR ; EGELSDLSR ; KLLSDILR } \\
\text {; LDILPIK ; AQIEIEIR ; LGDVEILR ; IGSLSLPR ; LLLPGELAK ; RIAEDSLLYFR ; ASCSERCVAR ; VATVPSLR ; LAVVITDGR ; EIIDLVLDR ; SSFFVAR ; } \\
\text { GDFQLPALR ; QEGAKDLLLR ; ATNLSNFR ; FASFLDK }\end{array}$ \\
\hline $\begin{array}{c}\text { ASM1 } \\
(11712)\end{array}$ & $\begin{array}{l}\text { AGFAGDDAPR ; GYSFTTTAER ; SYELPDGQVITIGNER ; VAPEEHPVLLTEAPLNPK ; VAIVITDGR ; VATVSLPR ; DYAIVDER ; LVALFDLR ; FQNALLVR ; } \\
\text { EDQTEYLEER ; QSIESVSPR ; IVIGLFGK ; LPVLETER ; FDCLLSR ; KLVLLNYER ; QLSGQQYR ; LLLTAAISADK ; IAFLVLK ; EPSPQSPQLHR ; VAVDTSYR }\end{array}$ \\
\hline $\begin{array}{c}\text { AIM2 } \\
(13977)\end{array}$ & $\begin{array}{l}\text { AGFAGDDAPR ; GYSFTTTAER ; EITALAPSTMK ; QEYDESGPSIVHR ; SYELPDGQVITIGNER ; VAPEEHPVLLTEAPLNPK ; DLYANTVLSGGSTMFPGIADR } \\
\text {; EISALAPATMK ; TTGIVMDSGDGVTHTVPIYEGYALPHAILR ; AVFPSIVGR ; DYAIVDER ; NFDGLDLDWEYPANR ; VAIVITDGR ; } \\
\text { IVMSQGTHLYFDHPYEPDPEER ; IALVITDGR ; GDGTGGLIYGDR ; IDVADLLR ; QLFDQVVK ; IGFPWSEIR ; APDFVFYAPR ; FGGTLADCIR ; STELLIR ; } \\
\text { LILPGELAK ; ISGLIYEETR ; EGIEAIEDDR ; IAIVITDGK ; IIIVDSLGR ; GWLEPLLR ; IDLLIPR ; ITQSNAILR ; VSIVITDGR ; LVALFDLR ; } \\
\text { TITLEVEPSDTIENVK ; SETLFLR ; DSTLIMQLLR ; QFGSSIAR ; IPVVLLNYMR ; ASDGVPQVIVVLTDGR ; IATFVLR ; QSIESVSPR ; LDDVHLR ; YSPVDPIR } \\
\text {; IAFLVLK ; IVIGLFGK ; EPSPQSPQLHR ; VAVDTSYR ; LSSPTALSDR ; HALSDAAVR ; VESVASLKER ; VPGVVTPR ; TPTDVPVNLSCGR ; } \\
\text { DLVGELADAIR ; SPIDLVR ; LIGWGQIR ; ILITGGAGFVGSHLVDR ; ; }\end{array}$ \\
\hline $\begin{array}{c}\text { ASM2 } \\
(13218)\end{array}$ & $\begin{array}{l}\text { FESNFNTQATNR ; NTDGSTDYGILQINSR ; DYAIVDER ; LLLPGELAK ; VFLENVIR ; ISGLIYEETR ; VAIVITDGR ; STELLIR ; LILPGELAK ; AGFAGDDAPR ; } \\
\text { GYSFTTTAER ; EITALAPSTMK ; QEYDESGPSIVHR ; VAPEEHPVLLTEAPLNPK ; VSIVITDGR ; LPLQDVYK ; YYVTIIDAPGHR ; TITLEVEPSDTIENVK ; } \\
\text { EGIEAIEDDR ; EDQTEYLEER ; EISALAPATMK ; LTAFLVR ; TGVSVSSLR ; YSPVDPIR ; ILVPQLDR ; EPSPQSPQLHR ; LSSPTALSDR ; IAFLVLK ; } \\
\text { INHDLLR ; GIVHTDLR ; ASDGVPQVIVVLTDGR ; QAAIVNGTPR ; IHSDCAANQQVTYR ; IVIGLFGK ; VAVDTSYR ; KLVLLNYER ; TANLETSLR ; } \\
\text { TLINEVDTR ; NFEEDFYR ; LMKFVTAVK ; NIIDLNTEMK ; SPIDLVR ; }\end{array}$ \\
\hline
\end{tabular}

Table 4: List of the peptides identified by MASCOT within each organic fraction of the shell matrix of Spirula spirula. For each fraction, the numbers in parentheses correspond to the number of peptides (number of queries) detected in total. 
529 ASMs. In each extract, the most represented AA residues are the hydrophobic ones, with a 530 peculiar emphasis on leucine, isoleucine and valine in all extracts. However, we observe that 531 all hydrophobic residues are more abundant in the insoluble matrices. The two acidic residues 532 (Asp, Glu) account for about 14\% of all residues, and the hydroxylated ones, around $13 \%$.

5347 residues while the longest, 30 . One can notice some variation on the identified number of 535 peptides, depending on the bleaching. We observe that there is a slight decrease of the number 536 of peptides from AIM1 to AIM2, and a significant increase from ASM1 to ASM2. relevance are the hits with specific enzymes that are putatively involved in biomineralization, such as "putative tyrosinase-like protein Tyr-3", a "probable chitinase 2", and a "serine protease

540 K12H4.7 precursor". Other candidates of interest are proteins that exhibit calcium-binding 541 properties (CBR-MUP-4 protein, transmembrane cell adhesion receptor MUA-3 precursor, and 542 a hypothetical protein HELRODRAFT_161577) and an immunoglobulin protein (IgGFc543 binding protein). Five identified proteins are thus found into the four matrices extracts: CBR-

544 MUP-4 from Caenorhabditis briggsae, putative tyrosinase-like from Crassostrea gigas, IgGFc-

\begin{tabular}{|c|c|c|c|c|}
\hline \multicolumn{3}{|c|}{ Protein hits } & \multirow{2}{*}{$\sum_{<}^{-1} \sum_{\frac{n}{<}}^{-1}$} & \multirow{2}{*}{$\sum_{\Sigma}^{N} \sum_{u}^{N}$} \\
\hline Id & Name & Organism & & \\
\hline gi|268575272 & C. briggsae CBR-MUP-4 protein & Caenorhabditis briggsae - nematode & & \\
\hline gi|405964315 & Putative tyrosinase-like protein tyr-3 & Crassostrea gigas - pacific oyster & & \\
\hline gi|405970334 & IgGFc-binding protein & Crassostrea gigas - pacific oyster & & \\
\hline gi|268570024 & C. briggsae CBR-CYN-5 protein & Caenorhabditis briggsae - nematode & & \\
\hline gi|158297124 & AGAP008053-PA, partial & Anopheles gambiae str. PEST - african malaria mosquito & & \\
\hline gi|284999807 & beta actin & Idiosepius paradoxus - nothern pygmy squid & & \\
\hline gi|323230 & polyprotein [Bovine viral diarrhea virus 1-Osloss] & & & \\
\hline gi|510849995 & core histone $\mathrm{H} 2 \mathrm{~A} / \mathrm{H} 2 \mathrm{~B} / \mathrm{H} 3 / \mathrm{H} 4$ & Ancylostoma ceylanicum - nematode & & \\
\hline gi|156359527 & $\begin{array}{l}\text { predicted protein } \\
\end{array}$ & Nematostella vectensis - starlet sea anemone & & \\
\hline gi|170578661 & $\begin{array}{l}\text { Transmembrane cell adhesion receptor mua-3 } \\
\text { precursor, partial } \\
\end{array}$ & Brugia malayi - filarial nematode worm & & \\
\hline gi $\mid 675868340$ & hypothetical protein HELRODRAFT_161577 & Helobdella robusta - californian leech & & \\
\hline gi|158300608 & AGAP012043-PA, partial & Anopheles gambiae str. PEST - african malaria mosquito & & \\
\hline gi|768189576 & hypothetical protein DICVIV_07943, partial & Dictyocaulus viviparus - bovine lungworm & & \\
\hline gi|669305641 & hypothetical protein M513_09906 & Trichuris suis - pig whipworm & & \\
\hline gi|163637123 & ribosomal protein S3, partial & Crassostrea gigas - pacific oyster & & \\
\hline gi|223016075 & actin & Octopus vulgaris - common octopus & & \\
\hline gi|524896874 & PREDICTED: peptidyl-prolyl cis-trans isomerase B-like & Aplysia californica - california sea hare & & \\
\hline gi| 170586872 & hypothetical protein Bm1_33780 & Brugia malayi - filarial nematode worm & & \\
\hline gi|33321997 & gamma-glutamyl phosphate reductase, partial & Lactobacillus delbrueckii subsp. Lactis - bacteria & & \\
\hline gi|676489609 & hypothetical protein LOTGIDRAFT_236342 & Lottia gigantea - owl limpet & & \\
\hline gi|748378928 & homeobox domain protein, partial & Ancylostoma duodenale - nematode & & \\
\hline gi|1360640 & 14-3-3 zeta protein & Xenopus laevis - African clawed frog & & \\
\hline gi|156544592 & PREDICTED: alpha-L-fucosidase-like & Nasonia vitripennis - jewel wasp & & \\
\hline gi| 193591718 & $\begin{array}{l}\text { PREDICTED: signal peptide, CUB and EGF-like domain- } \\
\text { containing protein } 1\end{array}$ & Acyrthosiphon pisum - pea aphid & & \\
\hline gi|542607731 & carbomoylphosphate synthase, partial & Culicoides immaculatus - diptera & & \\
\hline gi|307203534 & Probable chitinase 2 & Harpegnathos saltator - Jerdon's jumping ant & & \\
\hline gi|358337009 & monocarboxylate transporter 14 , partial & Clonorchis sinensis - chinese liver fluke & & \\
\hline gi|585686849 & PREDICTED: collagen alpha-3(VI) chain isoform X1 & Elephantulus edwardii - cape elephant shrew & & \\
\hline gi|225718928 & serine protease $\mathrm{K} 12 \mathrm{H} 4.7$ precursor & Caligus clemensi - sea louse & & \\
\hline gi| 8272602 & $82 \mathrm{kDa}$ heat shock protein 3 , partial & Philodina roseola - rotifer & & \\
\hline
\end{tabular}

Table 5: Summary of the main proteomic hits obtained by MASCOT and their presencelabsence (full box/empty box) within each fraction of the organic matrix. The hits mentioned here only represent those shared by, at least, two fractions; the list of the hits that are unique to each extract is available in the supplementary data 
545 binding from Crassostrea gigas, CBR-CYN-5 from Caenorhabditis briggsae and

546 AGAP008053-PA from Anopheles gambiae str. PEST. More strangely, we also find two hits 547 with the cytoskeletal protein actin (found in three extracts), and one hit with a histone, a nuclear 548 protein (also found in three extracts). Nine hits (on 31) are found with either hypothetical or 549 predicted proteins, most of them from invertebrate models, including two molluscs. So far, we 550 do not find any hits corresponding to proteins that exhibit either Low Complexity Domains 551 (LCDs) or Repetitive Low-Complexity domains (RLCDs).

552 The results of the search against the $S$. spirula transcriptome brought additional results 553 that are summarized in Table 6. In total, we obtained 39 hits: 27 with AIM1, 31 with AIM2, 10 554 with ASM1 and 12 with ASM2. Among them, 22 are shared: 6 between the 4 extracts, 7 555 between 3 of them and 9 between 2 . In the shared hits, the percentage of coverage varies from 556 almost 60 to $1.4 \%$. Furthermore, 17 hits are unique to one of the four extracts: 6 to AIM1, 9 to 557 AIM2, 1 to ASM1 and 1 to ASM2. It is interesting to note that he two AIMs generate more hits 558 than the ASMs, and the second extracts (AIM2, ASM2), more than the first ones (AIM1, 559 ASM1). Among the 6 hits shared by the four extracts, 4 of them are invariably the ones with 560 the highest peptidic coverage. They include a true transferrin, a serine protease inhibitor 561 (elastase-inhibitor like), a matrilin, and actin. The two other "shared by four" hits are an 562 uncharacterized protein with a heme-binding domain and a peptidyl prolyl cis trans isomerase. 563 Among the 7 hits shared by 3 extracts, four of them exhibit a peptidic coverage higher than $56410 \%$ of their sequence. They include $\alpha-2$ macroglobulin, collagen ( $\mathrm{N}$-terminus), a 565 protein/nucleic acid deglycase and a histone. The three other proteins are one ubiquitin and two 566 histones. The proteins shared by two extracts are represented by a calcium-binding protein, a 567 peptidyl-prolyl cis-trans isomerase, a chitobiase/sugar-binding protein, a GLIPR1 protein, a 568 transferrin fragment, a collagen N-terminus, and a lamin. The other 17 proteins found in one 569 extract include, among others, a Cys-rich secretory protein, a galectin3 binding-protein, a 570 calcium-binding protein and four enzymes involved in saccharidic moieties modifications 571 (heparan sulfate glucosamine sulfotransferase, $\mathrm{N}$-acetyl-galactosaminidase, chitin deacetylase, 572 UDP-glucuronic acid decarboxylase) 


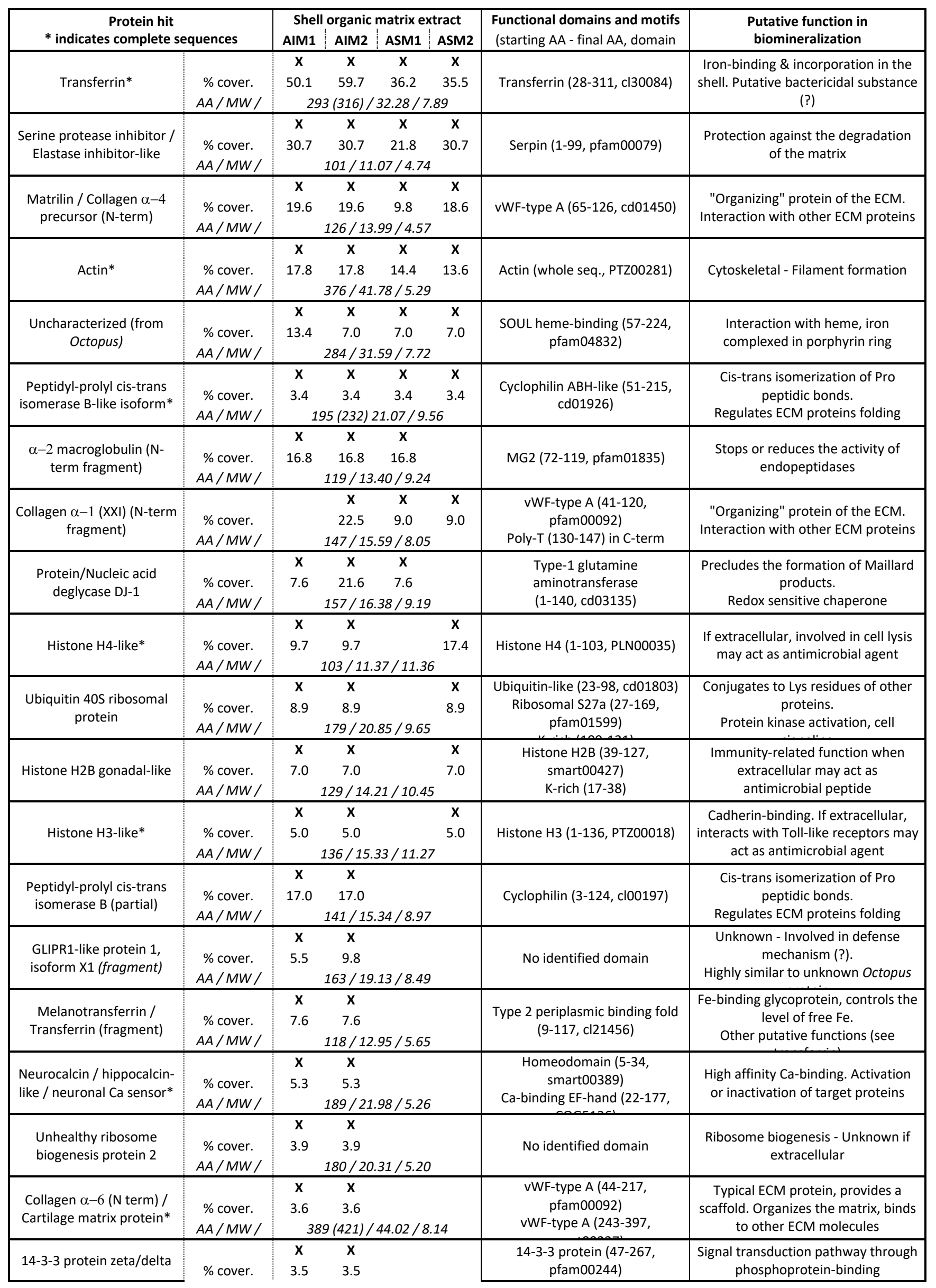




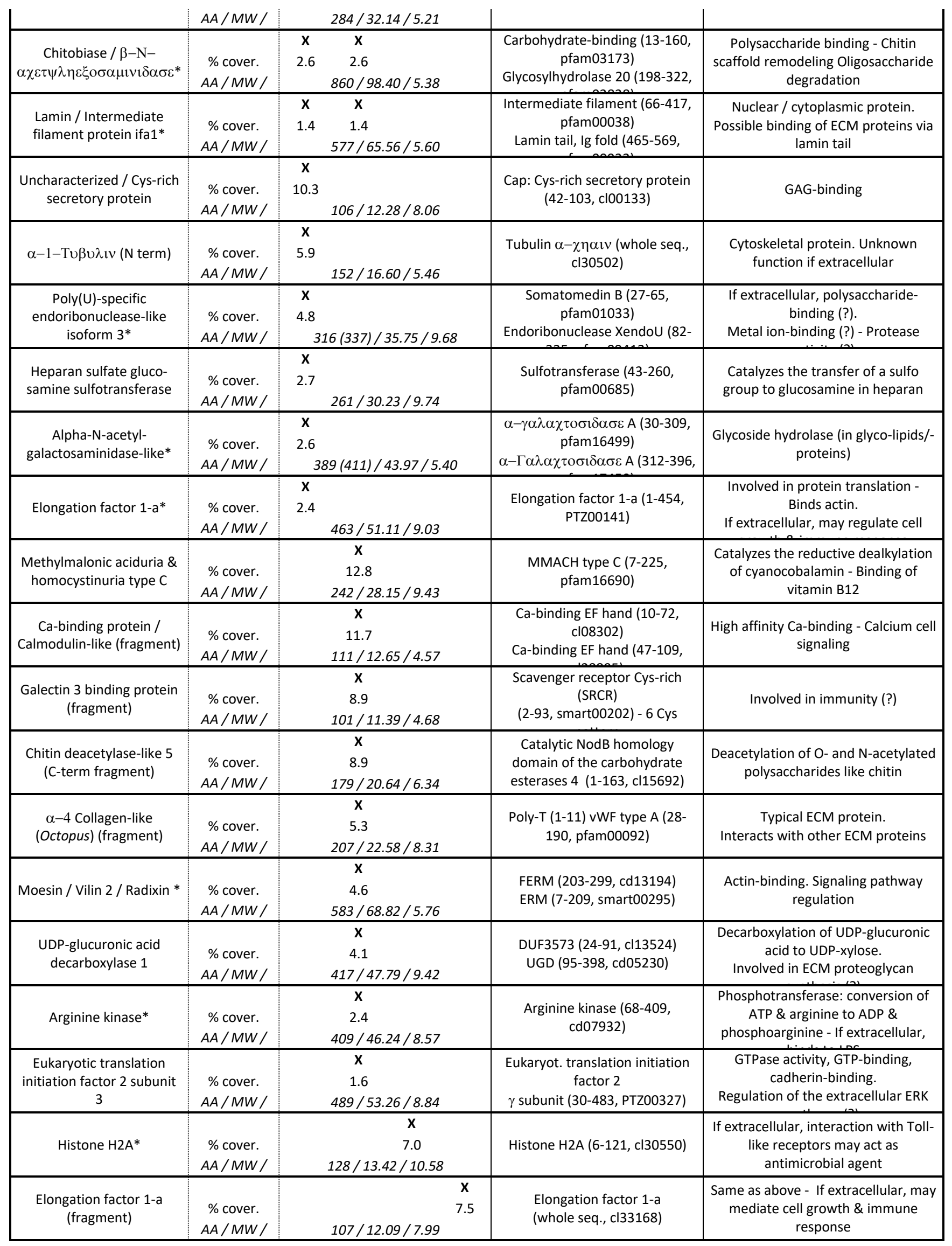


The present paper describes the shell structure and biochemistry of the Ram's Horn squid Spirula spirula. To our knowledge, this work represents the first exhaustive characterization of the shell matrix of this species. We describe both the microstructural features of the shell and the matrix biochemical fingerprint, with a particular emphasis on sugars and protein content.

From a microstructural viewpoint, our investigation confirms that the shell wall is made of two layers, as previously suggested (Dauphin, 1976, 1977; Cuif et al., 1983). However, we do not recognize the homogeneous semi-prismatic pattern described by these authors. We rather describe the internal layer as a succession of block-like/irregular semi-prismatic structures, and the external tuberculated layer as a regular semi-prismatic unit. A thin blackish layer between the two previous units is observable, which has already been noticed (Dauphin, 1976, 1977) and described as purely organic by Cuif et al. (1983) after an enzymatic treatment.

We also observe the lamello-fibrillar microstructure of the septa, usually considered as a nacreous layer (Barskov, 1973; Bøggild, 1930; Dauphin, 1976; Mutvei, 1964). Macroscopically, the septa exhibit indeed iridescence properties. However, we feel that the "nacreous" terminology is misleading and we follow the assertion of Erben (1972) who claimed that the nacre of Spirula and other coleoids is rather a 'false nacre' and recommended the use of "lamello-fibrillar" terminology. This expression is entirely justified in view of a very recently published work (Lemanis et al., 2020), which precisely visualizes the substructures of the lamello-fibrillar layer, and describes it as the stacking of "thin lamellae that are themselves composed of aragonitic rods that tend to be parallel within a lamella." The lamello-fibrillar terminology was also used by Fuchs et al. (2012) to describe the septal microstructure of ancestral spirulid coleoids. Two patterns are of particular importance: the insertion of the septa in the shell walls, and the presence of what resembles cameral deposit at the back of the insertion zone. The first one, although mentioned in earlier works (Bandel and Boletzky, 1979; Dauphin, 1976; Hoffmann et al., 2018), was neither fully described, nor schematized (Bandel and Boletzky, 1979). We confirm that the septa are sandwiched as a bevel in the internal wall. Such structures were also observed among the fossil relatives of Spirula (Doguzhaeva, 1996) and defined as "mural flap" (Fuchs et al., 2013): this character state may be an apomorphy of the Spirulida order. Given the thinness of the S. spirula shell, one can assume that a "sandwich" insertion considerably reinforces the overall shell mechanical properties and was consequently selected by evolution. However, Lemanis et al. (2020) questioned such hypotheses, demonstrating that mural flaps have "no notable structural function". The second pattern 608 deposits in the dorsal septal corner and mentioned by Appelöf (1893), Bøggild (1930) and 
610 defined by different terminologies: "supraseptal annular ridges" (Mutvei, 1964), or "adapical 611 ridge", "mural ridge" and "septal ring" (Lemanis et al., 2020). Their function is also to increase 612 the overall mechanical properties of the shell. However, their set-up appears enigmatic: as noted 613 by Dauphin (1976) and confirmed by our observations, their microstructure is in continuity with 614 the internal wall layer on which they lay. This suggests either a continuous growth from the 615 internal wall, or an epitaxial growth after a growth stop between the secretion of the wall and 616 that of the supraseptal annular ridges. The chronology of the different secretory steps of shell 617 construction is not discussed further here.

618 Beside the microstructure overview, the biochemical characterization of the shell of $S$. 619 spirula represents the core of the paper. To limit potential biases due to the geographical source 620 of the samples, we performed our experiments on two batches of specimens from two spots, 621 distant from each other (Canaries Islands, and Brazil). Our investigations revealed that the 622 biochemical fingerprints do not depend on the geographical origin: there is no significant 623 difference between the two batches, whatever technique used. From now, we will no longer 624 consider the provenance of the specimens, but only focus on the biochemical signature.

After a superficial bleaching, the total shell matrix of $S$. spirula represents, in all our extractions, about $1 \%$ of the shell weight, a value that classifies it among the matrix-rich shells such as nacro-prismatic ones (Palmer, 1992, 1983). Similarly to these latter, a large proportion of the matrix is insoluble in acetic acid, representing around $70 \%$ of the organic content. A second thorough bleaching treatment decreases drastically the amount of matrix, in particular of the insoluble fraction. Following the criteria defined primarily by Crenshaw (Crenshaw, 1972), this obviously suggests that the shell matrix of S. spirula-including the soluble fraction - is predominantly intercrystalline and not protected by the mineral phase during the second bleaching step. Another argument in favor of an intercrystalline position of the matrix is the moderate capacity of the soluble fraction to interact with the in vitro precipitation of calcium carbonate and the absence of any sign of inhibition even at high matrix concentration (16 $\mu \mathrm{g} /$ well and higher, not shown), these two properties being often associated to acidic, i.e. Asprich intracrystalline proteins (Albeck et al., 1993). This suggests that most of the soluble fraction of $S$. spirula is not strongly bound to the mineral phase.

Our combined biochemical and physical investigations show that the saccharidic moieties constitute a notable fraction of the matrix. In particular, the FTIR spectra reveal high 641 amplitude bands compared to those of proteinaceous moieties (amide), in both ASMs and 642 AIMs. This finding is further substantiated by the SS-NMR spectra acquired for the AIM 643 extracts which identify $\beta$-chitin and also additional polysaccharides that together constitute 
$\sim 80 \%$ of the insoluble fraction. This percentage is higher than that indicated in earlier works, which found a protein/chitin ratio around two (Degens et al., 1967; Hunt and Nixon, 1981). However, this latter value is certainly overestimated (in favor of proteins) because these authors employed harsh hydrolytic conditions that have likely degraded a part of the saccharide moieties. In our case, the abundance of chitin identified by SS-NMR confirms earlier findings based on monosaccharide analysis, which showed that both ASM and AIM are composed predominantly of the deacetylated form - due to hydrolytic conditions - of N-acetylglucosamine, the monomer of chitin (Dauphin and Marin, 1995). Such a composition where sugars predominate is rather unusual for matrices associated with mollusc shells: most of the works published so far on this type of materials tend to show that the saccharidic moieties are often much less abundant than the protein ones (Agbaje et al., 2018; Immel et al., 2016). Similarities of ASMs profiles with chitin, seen by FTIR, are also in agreement with the ELLA test, since the main chitin-binding lectins such as WGA, STL and LEL give the highest reactivity. The presence of chitin in ASMs may appear odd as this polymer is supposed to be particularly insoluble. This suggests different potential explanations that do not mutually exclude each other: 1 . Soluble non-crossed-linked chitin may exist per se in the ASM, which would be rather unusual. 2. N-acetylglucosamine oligomers (that "mimic" chitin and are consequently targeted by chitin-binding lectins) are bound to soluble protein core. 3 . From our discussion above, the chitin framework occupies an intercrystalline position in the biominerals; consequently, this framework is partly cleaved chemically in a random manner by sodium hypochlorite during the bleaching treatment, and then, released in solution during decalcification. Then, the cleaved fragments remain large enough not to be eliminated by subsequent ultrafiltration. It is interesting to notice that if chitin represents about $80 \%$ of the AIM, and that AIM itself accounts for about $70 \%$ of the whole matrix, this means that chitin represents between 50 and $60 \%$ of the matrix: in other words, this means that the matrix is more chitinous than proteinaceous. This character brings it close to the cuttlefish matrix (Stegemann, 1963), and consequently, to the Sepiidae.

Both insoluble extracts, AIM1 and AIM2, of S. spirula show phosphorous content that is inferred as being an integral part of the proteinaceous content most commonly through phosphorylation of the abundant tyrosine and/or serine sidechains (13\% as shown above). We therefore propose that the P-signals we have found, both via IR and SS-NMR, are likely associated with post-translationally modified amino acids. While phosphates in general, and phosphorylation in particular, are implicated in regulation of biomineralization, their exact 
677 identity and role herein, remain to be studied (Brauer and Sykes, 1984; Lowenstam, 1981; 678 Sviben et al., 2016).

679 To investigate further the biochemical fingerprint of the matrix, we performed 680 proteomics followed by two in silico investigations: one based on NCBI search on heterologous 681 metazoan models, the second one, on the recently acquired transcriptome of Spirula spirula. 682 The first approach identified around 200 peptides, from 7 to 30 residues long, but no complete 683 protein sequences. We are fully aware that this relatively small number of peptides - although 684 very informative - gives a very partial picture of its shell proteome and that this picture may be 685 biased. For example, among all the identified peptides - regardless of the matrix extract - the 686 hydrophobic amino acid residues are predominantly represented in our analysis, a property 687 often encountered in mollusc shell matrices (Marin et al., 2008). However, in the single bulk 688 amino acid analysis published so far on the shell matrix of S. spirula (Degens et al., 1967), 689 glutamic acid, serine and aspartic acid are more abundant than glycine, alanine and leucine. 690 However, the two sets of data cannot be compared for several reasons: one of them is that 691 Degens and coworkers analysed only the insoluble matrix, obtained after a harsh decalcification with a mixture of $\mathrm{HCl} / \mathrm{TCA}$ followed by $6 \mathrm{~N}$ hydrochloric acid hydrolysis.

Other technical biases, not discussed here, may hamper the interpretation of the 694 proteomic results (see Marin et al., 2016 for more details). Interestingly, the number of 695 identified peptides significantly increased between ASM1 and ASM2. Similarly to what likely 696 happens to chitin during the second bleaching treatment, we suggest that insoluble proteins are 697 randomly cleaved by sodium hypochlorite and consequently, partly solubilized, becoming components of the ASM2 fraction. In total, the overall peptides lead to the identification of 91 protein hits, which constitutes a low score, given the number of peptides. In any event, the peptides recognized several interesting hits, namely specific enzymes, such as tyrosinase, chitinase and serine protease, which constitute a part of the molecular toolkit frequently found in shell matrices (Marie et al., 2012; Marin et al., 2014). Tyrosinase is thought to be biomineralization-linked either by being involved in the melanin biosynthesis or in the periostracum formation (Arivalagan et al., 2016; Nagai et al., 2007; Zhang et al., 2006), while chitinase and serine protease are associated to organic matrix remodelling (Marin et al., 2016; Yonezawa et al., 2016). We also identified a set of sequences that can be related to nonmolluscan calcium-binding proteins, with either EF-hand, or EGF-like domains, both belonging to the "high-affinity - low capacity" category. Among the unexpected hits, one finds actin, the main cytoskeletal protein, and histone, a nuclear protein. The actin identified here is identical to that found in the cephalopods to Idiosepius paradoxus and Octopus vulgaris. The 
significance of the presence of actin and histone in a shell matrix is discussed below. We also

712 found the putative presence of IgG-Fc binding protein, a candidate that binds immunoglobulins, and which is involved in immune protection (Arivalagan et al., 2016; Harada et al., 1997). We did not detect proteins that exhibit Low Complexity Domains (LCDs) or Repetitive Low Complexity Domains (RLCDs) such as aspartic acid-rich proteins, with one exception: a peptide matching with a hypothetical protein from Helobdella robusta (Californian leech) that exhibits a very large C-terminal region composed of D-rich Low Complexity repeats.

The second approach we employed, based on the S. spirula transcriptome, generated another set of proteins: some of them, like actin, histones or calcium-binding, confirmed the hits found with MASCOT against the "other metazoans" database. Others, not identified before, are relevant in the context of biomineralization. Among the protein list shared with the four extracts, one finds the highly covered transferrin, a serine protease inhibitor, a matrilin and a peptidyl prolyl cis-trans isomerase B-like, in addition to actin and to an unknown protein with a heme-binding domain. Transferrin is a ferritic-ion-binding glycoprotein that controls the level of free iron in biological fluids and its activation requires the presence of an anion, preferably carbonate $\mathrm{CO}_{3}{ }^{2-}$. At first sight, transferrin might be involved in the incorporation of iron in the shell. However, its presence in the organic matrix may appear odd and the link between iron and calcium carbonate is rather tenuous. Indeed, unpublished data on the iron content of Spirula spirula shell (Y. Dauphin, pers. comm.) show that the different shell layers contain between 67 and $110 \mathrm{ppm}$ of this element, values that do not reflect any exceptional enrichment and fall in the range of most aragonitic mollusc shells (Masuda \& Hirano, 1980). We may consequently have to infer other functions than "iron incorporation". Interestingly, transferrin has been identified in the biomineral-associated matrices of two other calcifying systems: the cichlid fish otolith (Weigele et al., 2016) and the hen's eggshell (Nys et al., 1999). In the first model, a true transferrin has been clearly identified together with a transferrin domain-containing protein, OMP-1 (otolith matrix protein-1). It was suggested, without any experimental evidence, that transferrin is associated to the occurrence of ferric ions in the otolith, and to the presence of magnetite particles that are geomagnetic sensors. In the second model, transferrin is suspected to be multifunctional, by interacting with the formation of calcium carbonate and by playing a role in natural immunity (Giansanti et al., 2012). It is also suspected to act as a strong antimicrobial substance, by depriving bacteria of iron (Gautron, personal comm.). It is to note that beside the full-length transferrin present in the four extracts, we also identified a shortened variant of this protein present only in the two AIMs. The two transferrin sequences are $48 \%$ identical (69\% similar) and may display different functions. In addition to transferrins, we 
detected in the four extracts a nameless protein (covered at 7 to 13\%) with a SOUL hemebinding domain (pfam04832) which putatively complexes iron. This protein is $45 \%$ identical to an unknown protein (NCBI reference sequence XP_014780085.1) from the octopus Octopus bimaculoides. To broaden the circle of the relation between iron and biomineralization to other mollusc models, let's mention another protein with analogous functions, i.e., iron binding and storage: ferritin; ferritin was reported to be involved in shell formation of the pearl oyster Pinctada fucata but its function was not elucidated (Zhang et al., 2003). All these arguments combined together emphasize the underestimated - but not yet understood - role of iron in calcium carbonate biomineralization.

The elastase inhibitor-like isoform is a member of the SERPIN family (SERine Proteinase INhibitor), a large group of proteins that inhibit the activity of hydrolytic enzymes, such as elastase or cathepsin G. In the last decade, members of this protein family have been recurrently detected as major components of the matrices of multiple calcified tissues, including mollusc shell (Calvo-Iglesias et al., 2017; Marie et al., 2010; Marin et al., 2014). Although the molecular activity has never been firmly tested in vitro, protease inhibitors are usually believed to be part of a protective system that prevents the degradation of the calcifying matrix during mineral deposition, by proteolytic enzymes. More generally, they may also be involved in immune functions.

Third candidate of interest, matrilin is an acidic (theoretical pI 4.57) proteoglycanassociated protein and a major component of extracellular matrices (ECM) of various tissues. It comprises a von Willebrand type A domain (vWF-type A, simplified in VWA), commonly found in extracellular matrix proteins. This domain can bind several proteins of the ECM and is involved in cell adhesion (Whittaker and Hynes, 2002). It has been identified in diverse molluscan shell matrix proteins such as PIF (Suzuki et al., 2009) and many others (Arivalagan et al., 2017; Feng et al., 2017). In vertebrate calcified tissues, the VWA-containing matrilin is thought to act as an "organizing" protein of the ECM (Fresquet et al., 2010). In particular, it mediates interactions between collagens and proteoglycans. Its multiple functions are related to its ability to form filaments (Klatt et al., 2000). It is interesting to note that our analysis identified three other VWA domain-containing proteins that exhibit high similarity with diverse $\alpha$-collagens.

The identified peptidyl prolyl cis-trans isomerase B-like is an enzyme that exhibits a cyclophilin domain, which regulates protein folding by catalysing the cis-trans isomerization of proline imidic peptidic bonds. It has been shown to be involved in collagen maturation in general, but, more specifically, in the maturation of the tooth extracellular matrix during 
development in murine model (Pandya et al., 2017). Interestingly, in the shell matrix of $S$. spirula, beside the full-length member, we detected a shortened version of peptidyl prolyl cistrans isomerase $\mathrm{B}$, with a reasonably good $17 \%$ peptidic coverage, and corresponding to $60 \%$ of the C-terminus of the first sequence. This fragment is not identical but a variant that exhibits 75\% identity (and 89\% similarity) with the complete form. Curiously, while the latter is present in the four extracts, the short variant has been detected only in the two AIMs, which suggests that it is cross-linked with other matrix components.

In the protein set identified in three, two or one extract, some other hits are relevant in the biomineralization context. Our biochemical characterization underlines the quantitative importance of the carbohydrate moieties, in particular of chitin. Consequently, the proteomic analysis evidences logically enzymes that are involved, near or far, in the assembly, degradation and modification of extracellular saccharides, and more specifically, in the remodeling of the chitin scaffold: they include chitobiase, heparan sulfate glucosamine sulfrotransferase, a Nacetyl-galactosaminidase, chitin-deacetylase, the UDP-glucuronic acid decarboxylase. They are accompanied by a set of putative carbohydrate-binding proteins, like the Cys-rich secretory protein. The case of deglycase is interesting since this enzyme, identified in three extracts on four, is thought to prevent the formation of Maillard products, i.e., the reaction between sugars and amino acids. Thus, deglycase can be placed in the category of saccharide-interacting enzymes.

Other candidates of importance, the two calcium-binding proteins. Both are acidic (theoretical pI 4.57 and 5.26, respectively) and exhibit the typical EF-hand motif that binds calcium ions with high affinity. These proteins have been often identified in calcium carbonate associated matrices (Feng et al., 2017). They are thought to be part of the extracellular signaling machinery, rather than being involved in crystal nucleation or calcium ion transport for mineralization, a function that is usually attributed to low affinity - high capacity calciumbinding proteins, such as the aspartic-rich proteins, not detected here (Marin et al., 2008).

In Table 6, we identified a series of proteins that are not supposed to be present in the extracellular matrix since they are normally localized in the cytoplasmic or in the nucleus. The first ones include in particular cytoskeletal proteins, such as actin or tubulin, and other cytoplasmic partners that bind them, like elongation factors (actin-binding) or moesin/radixin. Nuclear proteins are represented by different histones (H2A, H2B, H3, H4) and lamin. For cytoskeletal proteins, we cannot exclude that these proteins are all cellular contaminants, in spite of the thorough cleaning of the skeletal tissues by sodium hypochlorite. We cannot rule out neither that a tight link exists between these proteins and the extracellular matrix, several 
813 evidences show it, in particular when vesicles are involved in the process: actin was found to 814 be a component of ECM (Accinni et al., 1983); in cartilage, it is associated to ECM in 815 mineralizing/demineralizing vesicles (Holliday et al., 2020; Rosenthal et al., 2011). In molluscs,

816 Weiss and coworkers evidenced the relationship between the cytoskeletal forces and the shell 817 forming matrix (Weiss et al., 2006), a concept that can be extended to other calcifying systems 818 (Tyszka et al., 2019). For histones, the identification of these very basic (lysine-rich) proteins 819 in a calcium carbonate-associated matrix is not new. It is generally believed that histones or 820 histone-derived peptides may function as antimicrobial agents. This hypothesis has been 821 repeatedly evoked for the eggshell matrix (Réhault-Godbert et al., 2011) and somehow confirmed in another model: Molluskin, an antimicrobial peptide identified in several molluscs, was found to derive from histone H2A (Sathyan et al., 2012). Clearly, the presence of nuclear or cytoplasmic proteins in the calcifying extracellular matrix needs to be reevaluated and explained accurately.

To summarize, the shell matrix of Spirula spirula, as seen by the MASCOT analysis of the protein-translated transcriptome of Spirula spirula, contains numerous molecular actors, including a minimum of 11 true enzymes and 28 proteins of very different functions. All these 39 members can be categorized as follows: extracelllular matrix proteins (matrilin, collagenlike) together with ECM-binding partners and ECM-interacting enzymes (like cis-trans isomerase) required for ECM protein folding and activation; a set of enzymes that regulate, modify and remodel the saccharidic moieties (chitin deacetylase, $\mathrm{N}$-acetylgalactosaminidase...) together with saccharide-binding proteins that are not enzymes; a set of cytoskeletal proteins (actin, lamin, tubulin) that function in extracellular environment together with their binding partners (elongation factor, moesin). The system includes also proteins involved in cell signaling (14-3-3 protein zeta, ubiquitin, protein with MMACH domain...) and calcium-binding proteins (hippocalcin-like, calmodulin-like). The system possesses also its protective functions at molecular and cellular levels, respectively: at molecular level, these are protease inhibitors on the one hand, and putative bactericidal factors (histones?), immunity-related proteins and possibly proteins that bind iron, on the other hand. Finally, the system contains a set of proteins of totally unknown functions, as exemplified by the unhealthy ribosome biogenesis protein 2 and GLIPR1 protein 1.

Are notably absent from this molecular landscape the following candidates usually 844 found in skeletal matrices: carbonic anhydrase and low complexity domain containing proteins. 845 Carbonic anhydrase (CA) is a key-enzyme in calcium carbonate biomineralization. It reversibly 846 catalyzes the conversion of $\mathrm{CO} 2$ to bicarbonate. In the protein-translated transcriptome of $S$. 
spirula, we identified three CA sequences, which possess tryptic cleavage sites (data not shown)

848 of which no peptide is present in the matrix proteomic results. This is a strong indication that

849 CA is not incorporated as a shell matrix protein in the Ram's Horn model. This conclusion confirms earlier finding on the shell matrix of the abalone Haliotis tuberculata (Le Roy et al., 2014) and shows that CA, depending on the mollusc model is or is not a shell matrix protein. The other absent players of the list are proteins that contain low complexity domains or repetitive low complexity domains. In calcium carbonate biomineralization, theses domains can be of several types, the most known being the acidic, aspartic acid-rich ones, and the hydrophobic "alanine/glycine-rich" domains (Marin et al., 2016). We admit that their underrepresentation in the protein list may be due to technical bias, such domains having few or no trypsin cleavage sites. Clearly, the absence of peptides exhibiting low complexity sequences does not mean that the corresponding proteins are absent from the shell formingmachinery: a separate analysis of the proteome-translated transcriptome (not shown) reveals putative candidates, which - for an unknown reason - are not incorporated to the matrix.

From an evolutionary viewpoint, it is puzzling that most of the peptides obtained do not exhibit any similarity with already known molluscan shell proteins. Among the few hits with molluscan proteins, the majority belongs to a bivalve, the Pacific oyster Crassostrea gigas (5 hits in total), while there are only two hits with a cephalopod, the common octopus Octopus vulgaris. A comparison of our peptide list with already published data on Sepia (Čadež et al., 2017; Le Pabic et al., 2017) and Nautilus (Marie et al., 2011, 2009) did not reveal any similarity. When compared with the complete transcriptome of Octopus bimaculoides (Albertin et al., 2015) our peptide dataset leads few hits, mainly with actin-like proteins (3 hits, exhibited by all the extract of the organic matrix of Spirula spirula) and H4 histones (9 hits in total, only with the ASM2 extract).

Such a paucity of hits with already studied cephalopods is intriguing but may be related to the uncertainty about the phylogenetic position of Spirula and to its unique evolutionary history, i.e., its relative evolutionary remoteness from other members of this mollusc class: indeed, within Decabrachia, the placement of the order Spirulida has historically been contentious (reviewed within Lindgren and Anderson, 2018). On the one hand, early phylogenetic studies based on a small number of genes proposed that Spirula occupies either a basal position relative to other Decabrachia (Allcock et al., 2011; Warnke et al., 2003) or that a sister taxa relationship exists between the two families Spirulidae and Sepiidae (Strugnell et al., 2005). These views are congruent with morphological characters such as a well-developed shell with chambers and septa. On the other hand, recent studies, including those based on more 
881

882

883

884

885

886

887

888

889

890

891

892

893

894

895

896

897

898

899

900

901

902

903

904

905

906

907

908

909

910

911

912

913

914

comprehensive molecular datasets, have recovered a sister taxon relationship between Spirulida and a clade containing Oegopsida ('open eyed' squids) and Bathyteuthoidea (mesopelagic to bathopelagic squids) (Lindgren et al., 2012; Strugnell et al., 2017). Similarly, Tanner et al. (2017) reported a sister taxon relationship between spirulid and oegopsid squids. Although these authors did not include bathyteuthoid squids in their analyses, a close phylogenetic relationship between bathyteuthoids and oegopsids is well established (e.g. Lindgren et al., 2012; Strugnell et al., 2005). Recent divergence time estimates, incorporating molecular and fossil data, suggest that spirulids and oegospids diverged around $128 \mathrm{Ma}$ (Tanner et al., 2017), which accords with appearance of stem group spirulids in the latest Cretaceous ( 66-72 Ma) (Fuchs et al., 2012).

The absence of any similarity with Nautilus is not surprising, considering the deep divergence time between the subclasses Nautiloidea (Nautilus) and Coleoidea (octopus, cuttlefishes and squids) ( 416 $\pm 60 \mathrm{Ma}$, Kröger et al., 2011). In addition, our study suggests that Spirula and Sepia have completely different molecular tools to construct their shell. This result is also not surprising. Sepiids and spirulids both possess an internal calcareous shell with a phragmocone and, as a result, they have extensive fossil records in comparison to other extant decabrachian lineages that have lost their shell (i.e., oegopsids, myopsids). The phragmocone is a plesiomorphic character within cephalopods and, therefore, the fact that it is present within sepiids and spirulids does not indicate that these lineages are closely related. In support of this, several recent phylogenetic studies have recovered a sister taxon relationship between sepiids and all remaining decabrachians (including spirulids) (Strugnell et al., 2017; Tanner et al., 2017; Uribe and Zardoya, 2017) with divergence of these two clades estimated to have occurred in the mid Jurassic (Tanner et al., 2017) or in the early Cretaceous (Uribe and Zardoya, 2017). This lapse of time is long enough to allow the independent evolution of the organic matrix proteins: recent findings suggest indeed that several skeletal matrix proteins exhibit a fast evolution rate (Jackson et al., 2006; McDougall et al., 2013). However, a rapid evolution of matrix components is not incompatible with the occurrence of very conservative characters, such as the abundance of chitin or the overall morphological similarities (septate inner shell, for example). Given the modern phylogenetic view of coleoids, which brings Spirulida as a sister group of the non-calcifying oegopsids, it would be relevant to determine how the molecular functions of the proteins used for calcification within Spirula have evolved in this latter clade. 
915 The authors thank 3P5 proteomic platform (University of Paris, Cochin Institute, 916 INSERM U1016, CNRS UMR8104, Paris). They also thank both Emmanuel Fara and Arnaud 917 Brayard (UMR 6282 Biogeosciences, Dijon) for their valuable comments and advices, and two 918 anonymous reviewers who contributed to improve the manuscript. At last, F. M. and M. O. 919 thank Yannicke Dauphin (UMR CNRS 7205 ISYEB, MNHN, Paris) for providing minor 920 element data on the shell of S. spirula. The work of M. Oudot, P. Neige and F. Marin was 921 supported mostly by annual recurrent CNRS funding of UMR Biogéosciences. Complementary 922 funding included CNRS-INTERRVIE project 'BECOME FREE' (F. Marin, 2019). The 923 contribution of I. Ben Shir and A. Schmidt was supported by the Israel Science Foundation 924 grant 2001/17.

925

926 Authors contribution

M. O. conducted the biochemical/structural characterization under the guidance of $\mathrm{F}$. 928 M.; L. P. performed FTIR spectroscopy, C. B., proteomic analyses, I. B. S. and A. S, SS-NMR 929 characterization. J. M. S., R. H., P. N. and A. L. provided samples. J. M. S. provided 930 transcriptomic data. M. O., F. M., and P. N. wrote the manuscript with inputs from A. S., L. P 931 and J. M. S. 


\section{Legends of figures}

963

Figure 1: Spirula spirula. A, specimen from East Australian coast (Townsville, Queensland). B, specimen from Thailand. Note that the first specimen still possesses its initial chamber, while it is missing in the second one.

Figure 2: Shell microstructures of Spirula spirula, in the insertion zone of a septum into the shell wall. A) General view, equatorial section. B) General view of the septum insertion in the outer wall. Note the beveled shape of the whole structure. C) Zoom on the very beginning of the septum into the shell outer wall, showing its organization into an internal unit, with an irregular semi-prismatic layer (s.irr. p). D) Zoom on the external unit of the shell wall, showing its tuberculated and regular semi-prismatic structure (t-r.p). E) Zoom on the lamello-fibrillar structure of the septum. F) Zoom on the contact zone between the septum and the internal shell unit, at the very beginning of the insertion, showing the transformation from the irregular semiprismatic structure into the lamello-fibrillar one. G) Zoom on the supraseptal annular ridge, observed on the aboral side, dorsal corner, of the septum. In spite of a thin delimitation between the annular ridge and the internal unit, one notices a microstructural continuity.

Figure 3: FT-IR spectra of the shell powder of Spirula spirula, of commercial $\alpha$-chitin and of the different organic fraction of the shell matrix (AIM1, AIM2, ASM1, ASM2) from both localities (i.e. Canaries, C, and Brazil, B). The "domains" of the characteristic absorption bands of protein and saccharidic moieties are highlighted, respectively, in pink and yellow. The values of the main absorption peaks are indicated under each of them, and colored in pink when identical to those of the commercial chitin.

Figure 4: 75.4 MHz ${ }^{13} \mathrm{C}$ CPMAS spectra of acid insoluble extracts (AIM1) of Spirula spirula shells from the Canaries and Brazil, and of $\alpha$-chitin standard (shrimp) showing that the organic content of AIM1 consists primarily of chitin (the dashed lines denote the characteristic peaks of chitin).

Fig. 5: $121.85 \mathrm{MHz}{ }^{31} \mathrm{P}$ CP MAS NMR spectra of the acid insoluble extract (AIM1) of Spirula spirula shells from the Canaries and Brazil. The peaks are centered at $-0.2 \mathrm{ppm}$ and are 
966 of similar normalized intensities (accounting for sample weights of 16.8 and $6.0 \mathrm{mg}$, 967 respectively). Each spectrum was obtained acquiring $2 \mathrm{k}$ transients.

968

969

970

971

972

973

974

975

976

977

978

979

980

981

982

983

984

985

986

987

988

989

990

991

992

993

994

995

996

997

998

999

Figure 6: SDS-Page gel electrophoresis on Spirula spirula. A) Silver-staining; B) Biorad blue staining; C) Stains-all. PM: standard molecular weight (Fermentas).

Figure 7: In-vitro crystallization assay performed on both soluble matrix extracts of Spirula spirula (Canaries Islands) ASM1 (top) and ASM2 (bottom). The black arrows indicate the increasing matrix concentration within each well, from 0 (blank) to $16 \mu \mathrm{g} /$ well (200 $\mu \mathrm{L}$ per well).

Table 1: Summary of the quantity and proportion of each organic shell matrix fraction (ASM, AIM) after on (batch 1) or two (batch 2) bleaching treatments. Separate data were obtained for samples of two different geographical sources, Canary Islands and Brazil.

Table 2: Summary of the reactivity pattern of lectins on both soluble fractions (ASM1 and ASM2) for both localities. 'XXXX' indicates a reactivity that exceeds $60 \%$, 'XXX', a reactivity comprised between 40 and 60\%, 'XX' between $20-40 \%$, ' $X$ ', between $10-20 \%$ and '-' for a reactivity below $10 \%$.

Table 3: Overview of the main proteomic results by MASCOT. A) Summary of the identified hits per extract. B) Cross-comparison of shared hits in the 4 extracts. C) Summary of the identified peptides per extract and occurrence of the most represented AA residues (sorted by decreasing order and colored according to their chemical properties: Blue: basic; red: acidic; orange; hydroxylated; green: hydrophobic)

Table 4: List of the peptides identified by MASCOT within each organic fraction of the shell matrix of Spirula spirula. For each fraction, the numbers in parentheses correspond to the number of peptides (number of queries) detected in total.

Table 5: Summary of the main proteomic hits obtained by MASCOT and their presence/absence (full box/empty box) within each fraction of the organic matrix. The hits mentioned here only represent those shared by, at least, two fractions; the list of the hits that are unique to each extract is available in the supplementary data. 
Table 6: Summary of the protein hits identified by MASCOT against the proteintranslated transcriptome of Spirula spirula. Each of the four fraction was analysed separately.

1003 The left column indicates the proteins identified, from the most (top) to the least (bottom) one represented. For each protein, the central colum indicates its occurrence in each fraction $(\mathbf{X})$, the peptidic coverage of the sequence (in \%) and the three successive numbers, its length 1006 (number of AA residues), its molecular weight (in kDa) and its isoelectric point, respectively. Five sequences exhibit an additional number in parentheses, indicating the full length of the sequence with it signal peptide. The central column lists the functional domains, identified by CD-search at NCBI, and some motifs, identified manually and currently found in skeletal matrix proteins. The numbers in parentheses indicate the starting and final AA residue of the conserved domains, and their accession number. Finally, the right column lists the putative function of the identified protein, in relation to shell formation. In particular, several proteins that are primarily cytoplasmic or nuclear (like histones) can also be found in extracellular environment. For these proteins, we tentatively list their function(s) in the context of extracellular biomineralization.

1016 Spirula spirula, of commercial $\alpha$-chitin and of the different organic fraction of the shell matrix.

Supp. Fig. 2: Additional SDS-Page gels after carbocyanine (Stains-all) staining, showing two more discrete bands on the ASMs, one at $17 \mathrm{kDa}$ and another one at very high molecular weight. tested. MASCOT was used against the "other metazoans" dataset. 
1029

1030

1031

1032

1033

1034

1035

1036

1037

1038

1039

1040

1041

1042

1043

1044

1045

1046

1047

1048

1049

1050

1051

1052

1053

1054

1055

1056

1057

1058

1059

1060

1061

1062

1063

1064

Accinni, L., Natali, P.G., Silvestrini, M., De Martino, C., 1983. Actin in the extracellular matrix of smooth muscle cells. An immunoelectron microscopic study. Conn. TIss. Res. 11, 6978.

Agbaje, O.B.A., Ben Shir, I., Zax, D.B., Schmidt, A., Jacob, D.E., 2018. Biomacromolecules within bivalve shells: Is chitin abundant? Acta Biomater. 80, 176-187. https://doi.org/10.1016/j.actbio.2018.09.009

Albeck, S., Aizenberg, J., Addadi, L., Weiner, S., 1993. Interactions of various skeletal intracrystalline components with calcite crystals. J. Am. Chem. Soc. 115, 11691-11697. https://doi.org/10.1021/ja00078a005

Albertin, C.B., Simakov, O., Mitros, T., Wang, Z.Y., Pungor, J.R., Edsinger-Gonzales, E., Brenner, S., Ragsdale, C.W., Rokhsar, D.S., 2015. The octopus genome and the evolution of cephalopod neural and morphological novelties. Nature 524, 220-224. https://doi.org/10.1038/nature14668

Allcock, A.L., Cooke, I.R., Strugnell, J.M., 2011. What can the mitochondrial genome reveal about higher-level phylogeny of the molluscan class Cephalopoda? Zool. J. Linn. Soc. 161, 573-586. https://doi.org/10.1111/j.1096-3642.2010.00656.x

Appellöf, A., 1893. Die schalen von Sepia, Spirula und Nautilus studien über den Bau und das Wachstum. K. Sven. VetenskAkad. Handl., Stock. 25, 1-106.

Arivalagan, J., Yarra, T., Marie, B., Sleight, V.A., Duvernois-Berthet, E., Clark, M.S., Marie, A., Berland, S., 2016. Insights from the shell proteome: Biomineralization to adaptation. Mol. Biol. Evol. 34, 66-77. https://doi.org/10.1093/molbev/msw219

Balmain, J., Hannoyer, B., Lopez, E., 1999. Fourier transform infrared spectroscopy (FTIR) and X-ray diffraction analyses and organic matrix during heating of mother of pearl (nacre) from the shell of the mollusk Pinctada maxima. J. Biomed. Mater. Res. 48, 749-754.

Bandel, K., Boletzky, S., 1979. A comparative study of the structure, development and morphological relationships of chambered cephalopod shells. Veliger 21, 313-354.

Barskov, S., 1973. Microstructure of the skeletal layers of Sepia and Spirula compared with the shell layers of other mollusks. J. Paleontol. 3, 285-294.

Bennett, A.E., Rienstra, C.M., Auger, M., Lakshmi, K. V, Griffin, R.G., 1995. Heteronuclear decoupling in rotating solids. J. Chem. Phys. 103, 6951-6958. https://doi.org/10.1063/1.470372

Bøggild, O.B., 1930. The shell structure of the mollusks. K. Dan. Vidensk. Selsk. Skr. Naturvidensk. Math. Afd. 9, 231-326.

Bouchet, P., Bary, S., Héros, V., Marani, G., 2016. How many species of molluscs are there in the world's oceans, and who is going to describe them? Mémoires du Muséum Natl. d'Histoire Nat. 208, 9-24. 
Brauer, M., Sykes, B.D., 1984. Phosphorus-31 nuclear magnetic resonance studies of phosphorylated proteins. Methods Enzymol. 107, 36-81. https://doi.org/10.1016/00766879(84)07005-1

Brayard, A., Escarguel, G., Bucher, H., Monnet, C., Brühwiler, T., Goudemand, N., Galfetti, T., Guex, J., 2009. Good genes and good luck: Ammonoid diversity and the end-permian mass extinction. Science 325, 1118-1121. https://doi.org/10.1126/science.1174638

Brock, G., Paterson, J., 2004. A new species of Tannuella (Helcionellida, Mollusca) from the early Cambrian of South Australia. Assoc. Australas. Palaeontol. Mem. 30, 133-143.

Bruun, A., 1943. The biology of Spirula spirula (L.). Dana Rep. 24, 1-46.

Čadež, V., Škapin, S.D., Leonardi, A., Križaj, I., Kazazić, S., Salopek-Sondi, B., Sondi, I., 2017. Formation and morphogenesis of a cuttlebone's aragonite biomineral structures for the common cuttlefish (Sepia officinalis) on the nanoscale: Revisited. J. Colloid Interface Sci. 508, 95-104. https://doi.org/10.1016/j.jcis.2017.08.028

Calvo-Iglesias, J., Pérez-Estévez, D., González-Fernández, Á., 2017. MSP22.8 is a protease inhibitor-like protein involved in shell mineralization in the edible mussel Mytilus galloprovincialis. FEBS Open Bio 7, 1539-1556. https://doi.org/10.1002/22115463.12286

Campbell, K., MacLennan, D., Jorgensen, A.O., 1983. Staining of the $\mathrm{Ca}^{2+}{ }^{2+b i n d i n g}$ proteins, calsequestrin, calmodulin, troponin $\mathrm{C}$, and S-100, with the cationic carbocyanine dye "Stains-all." J. Biol. Chem. 258, 11267-11273.

Checa, A.G., 2018. Physical and biological determinants of the fabrication of molluscan shell microstructures. Front. Mar. Sci. 5, 353. https://doi.org/10.3389/fmars.2018.00353

Clarke, M.R., 1970. Growth and development of Spirula spirula. J. Mar. Biol. Assoc. United Kingdom 50, 53-64. https://doi.org/10.1017/S002531540000059X

Crenshaw, M.A., 1972. The soluble matrix from Mercenaria mercenaria shell. Biomineralization 6, 6-11.

Cuif, J., Dauphin, Y., Denis, A., Gaspard, D., Keller, J., 1983. Etude des caractéristiques de la phase minérale dans les structures prismatiques du test de quelques mollusques. Bull. du Muséum Natl. d'histoire Nat. Sect. A, Zool. Biol. Ecologie Anim. 5, 679-717.

Dauphin, Y., 1996. The organic matrix of coleoid cephalopod shells: molecular weights and isoelectric properties of the soluble matrix in relation to biomineralization processes. Mar. Biol. 125, 525-529. https://doi.org/10.1007/BF00353265

Dauphin, Y., 1977. Microstructure et flottabilité chez la spirule (Cephalopoda). Comptes rendus Hebd. des séances l'Académie des Sci. Paris D 284, 2483-2485.

Dauphin, Y., 1976. Microstructure des coquilles de céphalopodes. I. Spirula spirula L. (Dibranchiata, Decapoda). Bull. du muséum natl. d'histoire Nat. 3ème série, $\mathrm{n}^{\circ}$ 382, Sci. de la Terre 54, 197-238.

Dauphin, Y., Marin, F., 1995. The compositional analysis of recent cephalopod shell carbohydrates by Fourier transform infrared spectrometry and high performance anion 
Degens, E.T., Spencer, D.W., Parker, R.H., 1967. Paleobiochemistry of molluscan shell proteins. Comp. Biochem. Physiol., 20, 553-579. doi:10.1016/0010-406x(67)90269-1

Doguzhaeva, L., 1996. Two early Cretaceous spirulid coleoids of the north-western Caucasus: their shell ultrastructure and evolutionary implications. Palaeontology 39, 681-707.

Erben, H.K., 1972. Uber die Bildung und das Wachstum von Perlmutt. Biomineralization 4, $15-46$.

Feng, D., Li, Q., Yu, H., Kong, L., Du, S., 2017. Identification of conserved proteins from diverse shell matrix proteome in Crassostrea gigas: characterization of genetic bases regulating shell formation. Sci. Rep. 7, 45754. https://doi.org/ 10.1038/srep45754

Fresquet, M., Jowitt, T.A., Stephen, L.A., Ylöstalo, J., Briggs, M.D., 2010. Structural and

Fuchs, D., Iba, Y., Ifrim, C., Nishimura, T., Kennedy, W.J., Keupp, H., Stinnesbeck, W., functional investigations of Matrilin-1 A-domains reveal insights into their role in cartilage ECM assembly. J. Biol. Chem. 285, 34048-34061. https://doi.org/10.1074/jbc.M110.154443 Tanabe, K., 2013. Longibelus gen. nov., a new Cretaceous coleoid genus linking Belemnoidea and early Decabrachia. Palaeontology 56, 1081-1106. https://doi.org/10.1111/pala.12036

Fuchs, D., Keupp, H., Trask, P., Tanabe, K., 2012. Taxonomy, morphology and phylogeny of Late Cretaceous spirulid coleoids (Cephalopoda) from Greenland and Canada. Palaeontology 55, 285-303. https://doi.org/10.1111/j.1475-4983.2011.01125.x

Giansanti, F., Leboffe, L., Pitari, G., Ippoliti, R., Antonini, G., 2012. Physiological roles of ovotransferrin. Biochim. Biophys. Acta 1820, 218-225. https://doi.org/10.1016/j.bbagen.2011.08.004

Grabherr, M.G., Haas, B.J., Yassour, M., Levin, J.Z., Thompson, D.A., Amit, I., Adiconis, X., Fan, L., Raychowdhury, R., Zeng, Q., Chen, Z., Mauceli, E., Hacohen, N., Gnirke, A., Rhind, N., di Palma, F., Birren, B.W., Nusbaum, C., Lindblad-Toh, K., Friedman, N., Regev, A., 2011. Full-length transcriptome assembly from RNA-Seq data without a reference genome. Nat. Biotechnol. 29, 644-652. https://doi.org/10.1038/nbt.1883

Harada, N., Iijima, S., Kobayashi, K., Yoshida, T., Brown, W.R., Hibi, T., Oshima, A., Morikawa, M., 1997. Human IgGFc binding protein (Fc $\gamma B P$ ) in colonic epithelial cells exhibits mucin-like structure. J. Biol. Chem. 272, 15232-15241. https://doi.org/10.1074/jbc.272.24.15232

Hare, P.E., 1963. Amino Acids in the Proteins from Aragonite and Calcite in the Shells of

Haring, E., Kruckenhauser, L., Lukeneder, A., 2012. New DNA sequence data on the enigmatic Spirula spirula (Linnaeus, 1758)(Decabrachia, suborder Spirulina). Ann. Naturhist. Mus. Wien. Ser. B Bot. Zool. 113, 37-48. 
Hoffmann, R., Lemanis, R.E., Wulff, L., Zachow, S., Lukeneder, A., Klug, C., Keupp, H., 2018. Traumatic events in the life of the deep-sea cephalopod mollusc, the coleoid Spirula spirula. Deep. Res. Part I Oceanogr. Res. Pap. 142, 127-144. https://doi.org/10.1016/j.dsr.2018.10.007

Holliday, L.S., De Faria, L.P., Rody, W.J., 2020. Actin and actin-associated proteins in extracellular vesicles shed by osteoclasts. Int. J. Mol. Sci., 21, art. numb. 158. https://doi.org/10.3390/ijms21010158

Hunt, S., Nixon, M., 1981. A comparative study of protein composition in the chitin-protein complexes of the beak, pen, sucker disc, radula and oesophageal cuticle of cephalopods. Comp. Biochem. Physiol., 68 B, 535-546. https://doi.org/10.1016/0305-0491(81)90071-7

Immel, F., Broussard, C., Catherinet, B., Plasseraud, L., Alcaraz, G., Bundeleva, I., Marin, F., 2016. The shell of the invasive bivalve species Dreissena polymorpha: biochemical, elemental and textural investigations. PLoS One 11, 1-28. https://doi.org/10.1371/journal.pone.0154264

Jackson, D.J., McDougall, C., Green, K., Simpson, F., Wörheide, G., Degnan, B.M., 2006. A rapidly evolving secretome builds and patterns a sea shell. BMC Biol. 4, 40. https://doi.org/10.1186/1741-7007-4-40

Jang, M.-K., Kong, B.-G., Jeong, Y.-I., Lee, C.H., Nah, J.-W., 2004. Physicochemical characterization of $\alpha$-chitin, $\beta$-chitin, and $\gamma$-chitin separated from natural resources. J. Polym. Sci. Part A Polym. Chem. 42, 3423-3432. https://doi.org/10.1002/pola.20176

Jastrzbski, W., Sitarz, M., Rokita, M., Bułat, K., 2011. Infrared spectroscopy of different phosphates structures. Spectrochim. Acta - Part A Mol. Biomol. Spectrosc. 79, 722-727. https://doi.org/10.1016/j.saa.2010.08.044

Kanold, J., Guichard, N., Immel, F., Plasseraud, L., Corneillat, M.,, Alcaraz, G., Brümmer, F., Marin, F., 2015. Spine and test skeletal matrices of the Mediterranean sea urchin Arbacia lixula - a comparative characterization of their sugar signature. FEBS J. 282, 1891-1905. https://doi.org/10.1111/febs.13242

Kaya, M., Baran, T., Mentes, A., Asaroglu, M., Sezen, G., Tozak, K.O., 2014. Extraction and Characterization of $\alpha$-Chitin and Chitosan from Six Different Aquatic Invertebrates. Food Biophys. 9, 145-157.

Kaya, M., Mujtaba, M., Ehrlich, H., Salaberria, A.M., Baran, T., Amemiya, C.T., Galli, R., Akyuz, L., Sargin, I., Labidi, J., 2017. On chemistry of $\gamma$-chitin. Carbohydr. Polym. 176, 177-186. https://doi.org/10.1016/j.carbpol.2017.08.076

Klatt, R.A., Nitsche, P., Kobbe, B., Mörgelin, M., Paulsson, M., Wagener, R., 2000. Molecular structure and tissue distribution of matrilin-3, a filament-forming extracellular matrix protein expressed during skeletal development. J. Biol. Chem. 275, 3999-4006.

Klug, C., Landman, N.H., Fuchs, D., Mapes, R.H., Pohle, A., Guériau, P., Reguer, S., Hoffmann, R., 2019. Anatomy and evolution of the first Coleoidea in the Carboniferous. Commun. Biol. 2, art. number 280. https://doi.org/10.1038/s42003-019-0523-2 
Kong, J., Yu, S., 2007. Fourier transform infrared spectroscopic analysis of protein secondary structures. Acta Biochim. Biophys. Sin. 39, 549-559.

Kröger, B., Vinther, J., Fuchs, D., 2011. Cephalopod origin and evolution: a congruent picture emerging from fossils, development and molecules: Extant cephalopods are younger than previously realised and were under major selection to become agile, shell-less predators. BioEssays 33, 602-613. https://doi.org/10.1002/bies.201100001

Lemanis, R., Stier, D., Zlotnikov, I., Zaslansky, P., Fuchs, D., 2020. The role of mural mechanics on cephalopod palaeoecology. J. R. Soc. Interface 17, 20200009. http://dx.doi.org/10.1098/rsif.2020.0009

Le Pabic, C., Marie, A., Marie, B., Percot, A., Bonnaud-Ponticelli, L., Lopez, P.J., Luquet, G., 2017. First proteomic analyses of the dorsal and ventral parts of the Sepia officinalis cuttlebone. J. Proteomics 150, 63-73. https://doi.org/10.1016/j.jprot.2016.08.015

Le Roy, N., Jackson, D.J., Marie, B., Ramos-Silva, P., Marin, F., 2014. The evolution of metazoan alpha-carbonic anhydrases and their roles in $\mathrm{CaCO}_{3}$ biomineralization. Front. Zool. 11, art. numb. 75. https://doi.org/10.1186/s12983-014-0075-8.

Lindgren, A.R., Anderson, F.E., 2018. Assessing the utility of transcriptome data for inferring phylogenetic relationships among coleoid cephalopods. Mol. Phylogenet. Evol. 118, 330342. https://doi.org/10.1016/j.ympev.2017.10.004

Lindgren, A.R., Pankey, M.S., Hochberg, F.G., Oakley, T.H., 2012. A multi-gene phylogeny of Cephalopoda supports convergent morphological evolution in association with multiple habitat shifts in the marine environment. BMC Evol. Biol. 12. https://doi.org/10.1186/1471-2148-12-129

Linné, C. von, 1758. Systema naturae per regna tria naturae :secundum classes, ordines, genera, species, cum characteribus, differentiis, synonymis, locis. Holmiae.

Lowenstam, H.A., 1981. Minerals formed by organisms. Science 211, 1126-1131. https://doi.org/10.1126/science. 7008198

Lu, S., Wang, J., Chitsaz, F., Derbyshire, M.K., Geer, R.C., Gonzales, N.R., Gwadz, M., Hurwitz, D.I., Marchler, G.H., Song, J.S., Thanki, N., Yamashita, R.A., Yang, M., Zhang, D., Zheng, C., Lanczycki, C.J., Marchler-Bauer, A., 2020. CDD/SPARCLE: the conserved domain database in 2020. Nucleic Acids Res. 48, D265-D268. https://doi: 10.1093/nar/gkz991

Marie, B., Joubert, C., Tayalé, A., Zanella-Cleón, I., Belliard, C., Piquemal, D., CochennecLaureau, N., Marin, F., Gueguen, Y., Montagnani, C., 2012. Different secretory repertoires control the biomineralization processes of prism and nacre deposition of the pearl oyster shell. Proc. Natl. Acad. Sci. U. S. A. 109, 20986-20991. https://doi.org/10.1073/pnas.1210552109

Marie, B., Marin, F., Marie, A., Bédouet, L., Dubost, L., Alcaraz, G., Milet, C., Luquet, G., 2009. Evolution of nacre: biochemistry and proteomics of the shell organic matrix of the cephalopod Nautilus macromphalus. ChemBioChem 10, 1495-1506. https://doi.org/10.1002/cbic.200900009 
Marie, B., Zanella-Cléon, I., Corneillat, M., Becchi, M., Alcaraz, G., Plasseraud, L., Luquet, G., Marin, F., 2011. Nautilin-63, a novel acidic glycoprotein from the shell nacre of Nautilus macromphalus. FEBS J. 278, 2117-2130. https://doi.org/10.1111/j.17424658.2011.08129.x

Marie, B., Zanella-Cléon, I., Le Roy;, N., Becchi, M., Luquet, G., Marin, F., 2010. Proteomic analysis of the acid-soluble nacre matrix of the bivalve Unio pictorum: detection of novel carbonic anhydrase and putative protease inhibitor proteins. ChemBioChem 11, 21382147. https://doi.org/10.1002/cbic.201000276

Marin, F., Bundeleva, I., Takeuchi, T., Immel, F., Medakovic, D., 2016. Organic matrices in metazoan calcium carbonate skeletons: Composition, functions, evolution. J. Struct. Biol. 196, 98-106. https://doi.org/10.1016/j.jsb.2016.04.006

Marin, F., Le Roy, N., Marie, B., Ramos-Silva, P., Wolf, S., Benhamada, S., Guichard, N., Immel, F., 2014. Synthesis of calcium carbonate biological materials: How many proteins are needed? Key Eng. Mater. 614, 52-61. https://doi.org/10.4028/www.scientific.net/KEM.614.52

Marin, F., Luquet, G., 2004. Molluscan shell proteins. Comptes Rendus Palevol 3, 469-492. https://doi.org/10.1016/J.CRPV.2004.07.009

Marin, F., Luquet, G., Marie, B., Medakovic, D., 2008. Molluscan shell proteins: primary structure, origin, and evolution. Curr. Top. Dev. Biol. 80, 209-276. https://doi.org/10.1016/S0070-2153(07)80006-8

Masuda, F., Hirano, M., 1980. Chemoical composition of some moderm pelecypod shells. Sci. Rep. Inst. Geosci. Univ. Tsukuba, sec B 1, 163-177.

McDougall, C., Aguilera, F., Degnan, B.M., 2013. Rapid evolution of pearl oyster shell matrix proteins with repetitive, low-complexity domains. J. R. Soc. Interface 10, 20130041. https://doi.org/10.1098/rsif.2013.0041

Mora, C., Tittensor, D.P., Adl, S., Simpson, A.G.B., Worm, B., 2011. How many species are there on earth and in the ocean? PLoS Biol. 9, 1-8. https://doi.org/10.1371/journal.pbio.1001127

Morrissey, J.H., 1981. Silver stain for proteins in polyacrylamide gels: a modified procedure with enhanced uniform sensitivity. Anal. Biochem. 117, 307-310. https://doi.org/10.1016/0003-2697(81)90783-1

Murray, J.W., 1985. Atlas of invertebrate macrofossils. Longman, The Palaeontological Association, Harlow, England.

Mutvei, H., 2018. Cameral deposits in Paleozoic cephalopods. GFF 140, 254-263. https://doi.org/10.1080/11035897.2018.1483966

Mutvei, H., 1964. On the shells of Nautilus and Spirula with notes on the shell secretion in noncephalopod molluscs. Ark. för Zool. 16, 221-278.

Nagai, K., Yano, M., Morimoto, K., Miyamoto, H., 2007. Tyrosinase localization in mollusc shells. Comp. Biochem. Physiol. - B Biochem. Mol. Biol. 146, 207-214. https://doi.org/10.1016/j.cbpb.2006.10.105 
Neige, P., Warnke, K., 2010. Just how many species of Spirula are there? A morphometric approach, , in: Tanabe, K., Shigeta, Y., Sasaki, T. \& Hirano, H. (Eds.), Cephalopods Present and Past. Tokai University Press, Tokyo, pp. 77-84.

Nishiguchi, M.K., Mapes, R.H., 2008. Cephalopoda, in: Ponder, W.F. \& Lindberg, D.R. (Eds.), Phylogeny and Evolution of the Mollusca. University of California Press, Berkeley, CA, pp. 163-199.

Nys, Y., Hincke, M.T., Arias, J.L., Garcia-Ruiz, J.M., Solomon, S.E., 1999. Avian eggshell mineralization. Avian Poult. Biol. Rev. 10, 143-166.

Ohkouchi, N., Tsuda, R., Chikaraishi, Y., Tanabe, K., 2013. A preliminary estimate of the trophic position of the deep-water ram's horn squid Spirula spirula based on the nitrogen isotopic composition of amino acids. Mar. Biol. 160, 773-779. https://doi.org/10.1007/s00227-012-2132-1

Palmer, A.R., 1992. Calcification in marine molluscs: how costly is it? Proc. Natl. Acad. Sci. U. S. A. 89, 1379-1382. https://doi.org/10.1073/pnas.89.4.1379

Palmer, A.R., 1983. Relative cost of producing skeletal organic matrix versus calcification: Evidence from marine gastropods. Mar. Biol. 75, 287-292. https://doi.org/10.1007/BF00406014

Pandya, M., Liu, H., Dangaria, S.J., Zhu, W., Li, L.L., Pan, S., Abufarwa, M., Davis, R.G., Guggenheim, S., Keiderling, T., Luan, X., Diekwisch, T.G.H., 2017. Integrative temporospatial, mineralogic, spectroscopic, and proteomic analysis of postnatal enamel development in teeth with limited growth. Front. Physiol. 8, 793. https://doi.org/10.3389/fphys.2017.00793

Pavat, C., Zanella-Cléon, I., Becchi, M., Medakovic, D., Luquet, G., Guichard, N., Alcaraz, G., Dommergues, J.L., Serpentini, A., Lebel, J.M., Marin, F., 2012. The shell matrix of the pulmonate land snail Helix aspersa maxima. Comp. Biochem. Physiol. - B Biochem. Mol. Biol. 161, 303-314. https://doi.org/10.1016/j.cbpb.2011.12.003

Ponder, W.F., Lindberg, D.R., Ponder, J.M., 2019. Biology and Evolution of the Mollusca. CRC Press.

Radev, L., Y. Mostafa, N., Michailova, I., M. M. Salvado, I., H. V. Fernandes, M., 2012. In Vitro bioactivity of collagen/calcium phosphate silicate composites, cross-linked with chondroitin sulfate. Int. J. Mater. Chem. 2, 1-9. https://doi.org/10.5923/j.ijmc.20120201.01

Réhault-Godbert, S., Hervé-Grépinet, V., Gautron, J., Cabau, C., Nys, Y., Hincke, M., 2011. Molecules involved in chemical defence of the chicken egg, in: Nys, Y., Bain, M., van Immerseel, F. (Eds.), Improving the Safety and Quality of Eggs and Egg Products - Egg Chemistry, Production and Consumption. Woodhead Publishing Series in Food Science, Technology and Nutrition , pp. 183-208. https://doi.org/10.1533/9780857093912.2.183

Rosenthal, A.K., Gohr, C.M., Ninomiya, J., Wakim, B.T., 2011. Proteomic analysis of articular cartilage vesicles from normal and osteoarthritic cartilage. Arthritis Rheum. 63, 401-411. https://doi.org/10.1002/art.30120 
Rusenko, K.W., Donachy, J.E., Wheeler, A.P., 1991. Purification and characterization of a shell matrix phosphoprotein from the american oyster, in: Sykes, C.S., Wheeler, A.P. (Eds.), Surface Reactive Peptides and Polymers - Discovery and Commercialization. ACS Symposium Series, 444. American Chemical Society, pp. 107-124. https://doi.org/doi:10.1021/bk-1991-0444.ch008

Sarashina, I., Yamaguchi, H., Haga, T., Iijima, M., Chiba, S., Endo, K., 2006. Molecular evolution and functionally important structures of molluscan dermatopontin: implications for the origins of molluscan shell matrix proteins. J. Mol. Evol. 62, 307-318. https://doi.org/10.1007/s00239-005-0095-2

Sathyan, N., Rosamma, P., Chaithanya, E.R., Anil Kumar, P.R., 2012. Identification and molecular characterization of Molluskin, a histone-H2A-derived antimicrobial peptide from molluscs. ISRN Mol. Biol. 2012, 219656. https://doi.org/10.5402/2012/219656

Schmitt, N., Marin, F., Thomas, J., Plasseraud, L., Demoy-Schneider, M., 2018. Pearl grafting: tracking the biological origin of nuclei by straightforward immunological methods. Aquac. Res. 49, 692-700. https://doi.org/10.1111/are.13499

Simkiss, K., Wilbur, K.M., 1989. Biomineralization. Cell biology and mineral deposition. Academic Press, San Diego. https://doi.org/https://doi.org/10.1016/B978-0-08-0925844.50001-9

Stegemann, H., 1963. Proteine (Conchagene) und chitin im stützgewebe von tintenfischen. Hoppe. Seylers. Z. Physiol. Chem. 331, 269-279. https://doi.org/10.1515/bchm2.1963.331.1.269

Stejskal, E.O., Schaefer, J., Waugh, J.S., 1977. Magic-angle spinning and polarization transfer in proton-enhanced NMR. Journal of Magnetic Resonance 28, 105-112. https://doi.org/10.1016/0022-2364(77)90260-8

Strugnell, J., Norman, M., Jackson, J., Drummond, A.J., Cooper, A., 2005. Molecular phylogeny of coleoid cephalopods (Mollusca: Cephalopoda) using a multigene approach; the effect of data partitioning on resolving phylogenies in a Bayesian framework. Mol. Phylogenet. Evol. 37, 426-441. https://doi.org/10.1016/j.ympev.2005.03.020

Strugnell, J.M., Hall, N.E., Vecchione, M., Fuchs, D., Allcock, A.L., 2017. Whole mitochondrial genome of the Ram's Horn Squid shines light on the phylogenetic position of the monotypic order Spirulida (Haeckel, 1896). Mol. Phylogenet. Evol. 109, 296-301. https://doi.org/10.1016/j.ympev.2017.01.011

Suzuki, M., Saruwatari, K., Kogure, T., Yamamoto, Y., Nishimura, T., Kato, T., Nagasawa, H., 2009. An acidic matrix protein, Pif, is a key macromolecule for nacre formation. Science 325, 1388-1390. https://doi.org/10.1126/science.1173793

Sviben, S., Gal, A., Hood, M.A., Bertinetti, L., Politi, Y., Bennet, M., Krishnamoorthy, P., Schertel, A., Wirth, R., Sorrentino, A., Pereiro, E., Faivre, D., Scheffel, A., 2016. A vacuole-like compartment concentrates a disordered calcium phase in a key coccolithophorid alga. Nat. Commun. 7, 11228. https://doi.org/10.1038/ncomms11228

Takeuchi, T., Plasseraud, L., Ziegler-Devin, I., Brosse, N., Shinzato, C., Satoh, N., Marin, F., 2018. Biochemical characterization of the skeletal matrix of the massive coral, Porites 
australiensis - The saccharide moieties and their localization. J. Struct. Biol. 203, 219229. https://doi.org/10.1016/j.jsb.2018.05.011

Tanner, A.R., Fuchs, D., Winkelmann, I.E., Ribeiro, M., Gilbert, M.T.P., Pankey, M.S., Kocot, K.M., Halanych, K.M., Oakley, T.H., Fonseca, R.R., Pisani, D., Vinther, J., Vinther, J., 2017. Molecular clocks indicate turnover and diversification of modern coleoid cephalopods during the Mesozoic Marine Revolution. Proc. R. Soc. B 284, 20162818.

Tyszka, J., Bickmeyer, U., Raitzsch, M., Bijma, J., Kaczmarek, K., Mewes, A., Topa, P., Janse, M., 2019. Form and function of F-actin during biomineralization revealed from live experiments on foraminifera. Proc. Natl. Acad. Sci. USA, 116, 4111-4116. https://doi.org/10.1073/pnas.1810394116

Uribe, J.E., Zardoya, R., 2017. Revisiting the phylogeny of Cephalopoda using complete mitochondrial genomes. J. Molluscan Stud. 83, 133-144. https://doi.org/10.1093/mollus/eyw052

Vinther, J., 2015. The origins of molluscs. Palaeontology 58, 19-34. https://doi.org/10.1111/pala.12140

Warnke, K., Plötner, J., Santana, J.I., Rueda, M.J., Llinas, O., 2003. Reflections on the phylogenetic position of Spirula (Cephalopoda): preliminary evidence from the $18 \mathrm{~S}$ ribosomal RNA gene. Berliner Paläobiol. Abh. 3, 253-260.

Weigele, J., Franz-Odendaal, T.A., Hilbig, R., 2016. Not all inner ears are the same: otolith matrix proteins in the inner ear of sub-adult cichlid fish, Oreochromis Mossambicus, reveal insights into the biomineralization process. Anat. Rec. 299, 234-245. https://doi.org/10.1002/ar.23289

Weiner, S., 1983. Mollusk shell formation: isolation of two organic matrix proteins associated with calcite deposition in the bivalve Mytilus californianus. Biochemistry 22, 4139-4145. https://doi.org/10.1021/bi00286a023

Weiss, I.M., Schönitzer, V., Eichner, N., Sumper, M., 2006. The chitin synthase involved in marine bivalve mollusk shell formation contains a myosin domain. FEBS Lett. 580, 18461852. https://doi.org/10.1016/j.febslet.2006.02.044

Whittaker, C.A, Hynes, R.O., 2002. Distribution and evolution of von Willebrand:integrin a domains: widely dispersed adhesion and elsewhere. Mol. Biol. Cell 13, 3369-3387. https://doi.org/10.1091/mbc.E02-05-0259

Yonezawa, M., Sakuda, S., Yoshimura, E., Suzuki, M., 2016. Molecular cloning and functional analysis of chitinases in the fresh water snail, Lymnaea stagnalis. J. Struct. Biol. 196, 107118. https://doi.org/10.1016/j.jsb.2016.02.021

Zhang, C., Xie, L., Huang, J., Chen, L., Zhang, R., 2006. A novel putative tyrosinase involved in periostracum formation from the pearl oyster (Pinctada fucata). Biochem. Biophys. Res. Commun. 342, 632-639. https://doi.org/10.1016/j.bbrc.2006.01.182

Zhang, Y., Meng, Q., Jiang, T., Wang, H., Xie, L., Zhang, R., 2003. A novel ferritin subunit involved in shell formation from the pearl oyster (Pinctada fucata). Comp. Biochem. 
Physiol. Part B Biochem. Mol. Biol. 135, 43-54. https://doi.org/10.1016/S10964959(03)00050-2 